Please do not destroy or throw away this publication. If you have no further use for it write to the Geological Survey at Washington and ask for a frank to return it

UNITED STATES DEPARTMENT OF THE INTERIOR

Harold L. Ickes, Secretary

GEOLOGICAL SURVEY

w. C. Mendenhall, Director

Professional Paper 185-C

\title{
THE RECOGNIZABLE SPECIES OF THE GREEN RIVER FLORA
}

BY

ROLAND W. BROWN

Shorter contributions to general geology, 1934-35

(Pages 45-77)

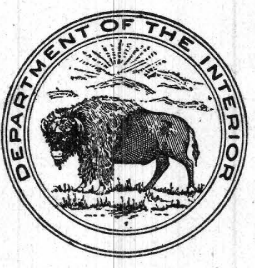

UNITED STATES GOVERNMENT PRINTING OFFICE WASHINGTON : 1934 


\section{CONTENTS}

Abstract

Introduction

Synonyms, changes of name, and rejections.

The recognizable species of the Green River flora

The significant species of the flora

Systematic descriptions_ _.

\section{ILLUSTRATIONS}

Plates 8-15. Fossil plants from the Green River formation 


\title{
THE RECOGNIZABLE SPECIES OF THE GREEN RIVER FLORA
}

\author{
By Roland W. Brown
}

\begin{abstract}
The identification of new collections of fossil plants from the Green River formation of middle Eocene age made it necessary to reexamine the megascopic types of the Green River flora. This study resulted in the reassignment of some species and the rejection of such species as were based on fragmentary, indefinable specimens. The recent collections yielded 22 new species. Exclusive of the mieroscopic forms of thallophytes and pollens, the flora now numbers 135 megascopic species that are considered to be recognizable and distinctive. The new elements found in the flora do not alter the previously expressed opinion that the megascopic Green River flora lived in a warm-temperate well-watered environment.
\end{abstract}

\section{INTRODUCTION}

The middle Eocene Green River shales of western Colorado, eastern Utah, and southwestern Wyoming continue to yield new fossil material that enlarges our knowledge of the Green River flora and tends to clarify our notions of the general environmental situation of the Green River lakes. The plants described in this paper are largely contained in recent collections or acquisitions by persons or institutions not connected with the United States Geological Survey, through whose courtesy I was permitted to examine the collections and to describe such species as may be new to science. Grateful acknowledgment for these favors is hereby made to Prof. T. D. A. Cockerell and Prof. Junius Henderson, of the University of Colorado; Dr. Ira Edwards, of the Milwaukee Public Museum; Prof. O. M. Ball, of the Agricultural and Mechanical College of Texas; and the late Dr. Arthur Hollick, of the New York Botanical Garden.

For a few days during the field season of $1930 \mathrm{I}$ accompanied W.H. Bradley, of the Geological Survey, on a visit to outcrops of the Green River formation in southwestern Wyoming. We made small collections of fossil plants near the classic fossil fish localities at Fossil and Green River, Wyo. These as well as all the collections mentioned above came from the upper part of the Green River formation.

During the process of identifying the specimens in the new collections I reexamined the types of the Green River fossil flora in the United States National Museum. This study resulted in the discovery that some species not originally included in the flora by Knowlton ${ }^{1}$ had the same matrix and were from the

\footnotetext{
1 Knowlton, F. H., Revision of the flora of the Green River formation: U.S. Geol. Survey Prof. Paper 131, pp. 133-182, 1923.
}

same locality as other species which he did include. No doubt these species were overlooked because they had been stored among other scattered collections. With the addition of these strays, the transfer of some species to their proper synonymy, and the exclusion of ill-defined or unrecognizable forms, the Green River floral list now presents a body of fairly well characterized species. Though some of the species in this list may not be correctly allocated botanically, it is hoped that they have been segregated so distinctly as to be clearly recognizable and therefore practically useful in making future identifications.

Our knowledge of the Green River flora is probably still meager in comparison to what it may be eventually. At the test pits of oil-shale prospectors in all parts of the region where the formation crops out there doubtless exist plant remains which await discovery and collection.

The Green River flora is definitely of middle Eocene age, because the deposits in which it occurs lie stratigraphically above the Wasatch formation and below the Bridger formation. This flora, therefore, has some importance as a standard of comparison in the discussion of the geologic age and the biologic relations of floras which preceded or followed it in the same or adjoining regions. The Fort Union and Florissant floras are two in which particular interest centers; but before adequate comparisons can be made with these floras they must be restudied and revised. The Fort Union flora is clearly older than the Green River flora, because it occurs in beds that lie beneath the Wasatch, which in turn lies beneath the Green River formation. On the other hand, it is not so clear that the Florissant flora is as much younger than the Green River as has been supposed. Placed in parallel columns, the identical or nearly identical species common to both floras are as follows:

\begin{tabular}{|c|c|}
\hline \multirow{2}{*}{$\begin{array}{l}\text { Green River } \\
\text { Populus wilmattae }\end{array}$} & \\
\hline & Populus pyrifolia \\
\hline Salix cockerell______ & Salix florissanti \\
\hline Myrica minuta_. & Myrica drymeja \\
\hline Juglans crossii & Juglans magnifica \\
\hline Hicoria juglandiformis & Hicoria juglandiformis \\
\hline Quercus drymeja_-_- & Quercus drymeja \\
\hline Celtis mecoshii _._. & Celtis mccoshii \\
\hline Lomatia coloradensis_. & Lomatia terminalis \\
\hline Lomatia acutiloba_-_._- & Lomatia acutiloba \\
\hline Banksites lineatulus_._- & Banksites lineatus \\
\hline & Odostemon florissantensi \\
\hline
\end{tabular}


Green River

Liquidambar callarche.

Amygdalus gracilis_

Mimosites coloradensis

Cassia hesperia

Podogonium americanum

Ailanthus lesquereuxi

Rhus variabilis

Sapindus dentoni

Koelreuteria viridifluminis

Ilex coloradensis

Parthenocissus tertiaria

Tilia scudderi

Sterculia coloradensis

Fraxinus flexifolia

Apocynophyllum wilcoxense

Sambucus? winchesteri
Florissant Liquidambar convexum Amygdalus gracilis Mimosites linearis Cytisus florissantianus Podogonium acuminatum Ailanthus americana Rhus coriaroides Sapindus coloradensis Koelreuteria alleni Ilex leonis Parthenocissus osborni Tilia populifolia Sterculia engleri Fraxinus mespilifolia Apocynophyllum pealii Sambucus ellisiae

It would appear, therefore, from their commonalty of species and general composition, together with their relative geographic contiguity, that these two floras were closely related biologically. That they may have been separated by a considerable time interval is possible but in my opinion is not definitely established.

A flora closely related to and of the same or approximately the same age as the Green River flora is that described by Berry ${ }^{2}$ from the Wind River Basin of Wyoming, in which he finds 21 species common to the two fioras. Berry ${ }^{3}$ has also recently described a few small collections from localities in Wyoming at horizons called lower Bridger and so-called "Bridger." The fossils, with one exception, are Green River species and indicate that the Green River type of flora continued into Bridger time.

A subtropical flora, said by Chaney and Sanborn ${ }^{4}$ to be of upper Eocene or lower Oligocene age, has recently been described from Goshen, Oreg., by those authors. Although I have seen few of the type or duplicate specimens of this flora, I judge from a comparison of the published illustrations with the types of the Green River flora that there is little if anything common to the two floras. Ocotea eocernua and Astronium oregonum, of the Goshen flora, are somewhat comparable with and may be related to Oreodaphne coloradensis and Rhus variabitis, respectively, of the Green River flora.

The number of species common to the Green River flora and the early Tertiary floras recorded from areas to the east and southeast, namely, the Denver, Raton, Wilcox, Claiborne, and Jackson floras, is not significant enough to indicate more than a distant relationship. This relationship, however, appears to be closer than that with the Goshen flora to the west.

\footnotetext{
${ }^{2}$ Berry, E. W., A flora of Green River age in the Wind River Basin of Wyoming: U.S. Geol. Survey Prof. Paper 165, pp. 55-79, pls. $6-15,1930$

${ }^{3}$ Berry, E. W., Eocene plants from Wyoming: Am. Mus. Novitates, no. 527,1932 .

${ }^{4}$ Chaney, R. W., and Sanborn, E. I., The Goshen flora of westcentral Oregon: Carnegie Inst., Washington Pub. 439, p. 64, 1933.
}

\section{SYNONYMS, CHANGES OF NAME, AND REJECTIONS}

The restudy of the type specimens of the Green River flora in the light of new material included in a few large collections makes the following changes necessary. The reasons for the changes, unless given immediately, are fully stated in the systematic descriptions of the several species.

Acer lesquereuxii Knowlton. Seed=Acer mysticum Kirchner. Ailanthus longepetiolata Lesquereux. Leaf $=$ Rhus longepetialata (Lesquereux) Brown, n. comb. Seed=Ailanthus lesquereuxi Cockerell.

Alnus kefersteinii (Goeppert) Unger. Lesquereux, U.S. Geol. Survey Terr. Rept., vol. 7 , p. 140 , pl. 64 , fig. 11, 1878= Viburnum asperum Newberry.

Banisteria bradleyi Brown=Cassia hesperia Brown.

Banksia cockerelli Brown=Salix longiacuminata Knowlton. Betula eocenica Brown=Betula coloradea Brown, n. name.

Bumelia coloradensis Cockerell=Leguminosites lesquereuxiana Knowlton.

Caenomyces eucalpytae Knowlton=Sphaerites, species of.

Caenomyces planerae Brown=Sphaerites, species of.

Caenomyces sapindicola Knowlton $=$ Sphaerites, species of.

Carpolithus capsularis Brown=Carpites viburni Lesquereux.

Carpolithus ellipticus Brown=Carpolithus prunoides Brown, n. name.

Celtis debequensis Brown=Celtis mccoshii Lesquereux.

Cinnamomum scheuchzeri Heer. Lesquereux, U.S. Geol. Survey Terr. Rept., vol. 8, p. 38, fig. $6,1883=$ Ficus wyomingiana Lesquereux.

Cissus parrottiaefolia Lesquereux. See Knowlton, U.S. Geol. Survey Prof. Paper 131, p. 170, 1923. Rejected. Locality doubtful.

Comptonia? anomala Knowlton=Planera inequilateralis (Lesquereux) Knowlton.

Cyperus chavannesi Heer. See Knowlton,. U.S. Geol. Survey Prof. Paper 131, p. 152, 1923. Rejected. Specimens missing. Locality doubtful.

Dalbergia knowltoni Cockerell=Leguminosites lesquereuxiana Knowlton.

Dalbergia viridiflumensis Knowlton=Planera nervosa Newberry.

Euonymus flexifolius Lesquereux=Fraxinus flexifolia (Lesquereux) Brown, n.comb.

Fious alkalina Lesquereux = Juglans alkalina Lesquereux.

Ficus tenuinervis Lesquereux=Cercis tenuinervis (Lesquereux) Brown, n.comb.

Ficus ungeri Lesquereux=Juglans schimperi Lesquereux.

Fraxinus petiolata Brown=Fraxinus flesifolia (Lesquereux) Brown, n.comb.

Ilex? affinis Lesquereux $=Q$ uercus castaneopsis Lesquereux. Ilex maculata Lesquereux $=Q$ uercus castaneopsis Lesquereux. Ilex wyomingiana Lesquereux $=Z i z y p h u s$ cinnamomoides Lesquereux.

Juglans occidentalis Newberry= Juglans schimperi Lesquereux. Juglans winchesteri Knowlton=Juglans alkalina Lesquereux. Juncus sp. Lesquereux. See Knowlton, U.S. Geol. Survey Prof. Paper 131, p. 155, 1923. Rejected. Specimens missing.

Leguminosites alternans Lesquereux. See Knowlton, idem, p. 165. Rejected. Not figured. Specimens missing.

Lomatia? microphylla Lesquereux. See Knowlton, idem, p. 162. Rejected. Types missing. Locality doubtful.

Lygodium dentoni Lesquereux. See Knowlton, idem, p. 150. Rejected. Types missing. Locality doubtful. 
Melia coloradensis Cockerell=Lomatia coloradensis (Knowlton) Brown.

Mimosites debequensis Brown=Mimosites coloradensis Knowlton.

Mimosites falcatus Brown = Mimosites coloradensis Knowlton.

Myrica luduvigii Schimper. See Knowlton, U.S. Geol. Survey Prof. Paper 131, p. 157, 1923=Rhus variabilis (Newberry) Knowlton.

Myrica salicina Unger. See Knowlton, idem, p. 156. Rejected. Not figured. Specimen missing.

Myrica torreyi Lesquereux. Brown, U.S. Geol. Survey Prof. Paper 154, p. 283, $1929=$ Sapindus dentoni Lesquereux.

Myrica undulata? Heer. Lesquereux, U.S. Geol. Survey Terr. Rept., vol. 7, p. 131, pl. 17, figs. 6-8, $1878=$ Rhus variabilis (Newberry) Knowlton.

Myrica zachariensis Saporta. Lesquereux, U.S. Geol. Survey Terr. Rept., vol. 8, p. 146, pl. 45a, figs. 6-9 [not pl. 25, fig. 5], $1883=$ Rhus variabilis (Newberry) Knowlton.

Myrica sp. Knowlton, U.S. Geol. Survey Prof. Paper 131, p. 157 , pl. 37 , fig. 2, 1923=Rhus variabilis (Newberry) Knowlton; idem, p. 158 , pl. 40, fig. $13=$ Salix longiacuminata Knowlton.

Odostemon reynoldsii Hollick = Fraxinus flexifolia (Lesquereux) Brown, n.comb.

Oreodaphne knowltoni Brown=Oreodaphne lancifolia (Lesquereux) Brown, n.comb.

Phyllites fremonti Unger. See Knowlton, U.S. Geol. Survey Prof. Paper 131, p. 176, 1923. Rejected. Type lost. Locality doubtful.

Pimelea spatulata Knowlton=Lomatia coloradensis (Knowlton) Brown.

Pontederites thecoides Hollick=Sparganium antiquum $(\mathrm{New}$ berry) Berry.

Fopulus scudderi Cockerell=Tilia scudderi (Cockerell) Brown, n.comb.

Quercus neriifolia Al. Braun. Lesquereux, U.S. Geol. Survey Terr. Rept., vol. 8, p. 155, pl. 31, fig. 12, 1883=Amygdalus gracilis Lesquereux.

Rhus lesquereuxii Knowlton and Cockerell. See Knowlton, U.S. Geol. Survey Prof. Paper 131, p. 167, 1923. Rejected. Not figured. Specimen missing.

Rhus myricoidles Knowlton=Rhus variabilis (Newberry) Knowlton. Brown, U.S. Geol. Survey Prof. Paper 154, p. 287, pl. 73, fig. 9, 1929=Rhus longepetiolata (Lesquereux) Brown, n.comb.

Rhus nigricans (Lesquereux) Knowlton=Rhus variabilis (Newberry) Knowlton.

Salix linearis Knowlton=Myrica minuta Knowlton.

Salix sp. Knowlton, U.S. Geol. Survey Prof. Paper 131, p. 156, pl. 37, figs. 3, 5, 1923=Planera nervosa Newberry; fig. $4=$ Apocynophyllum roanense Brown, n.sp.

Salix sp. [Salix media Heer]. Knowlton, idem, p. 156= Sapindus dentoni Lesquereux.

Sapindus lancifotius Lesquereux, U.S. Geol. Survey Terr. Rept., vol. 8, p. 182 , pl. 37, fig. 9, 1883=Oreodaphne lancifolia (Lesquereux) Brown, n.comb.; pl. 32, figs. 3-6=Sapindus dentoni Lesquereux.

Sophora coloradensis Knowlton=Leguminosites lesquereuæiana Knowlton.

Sphaerites myricae Lesquereux $=$ Sphaerites, species of.

Staphylea viridifluminis Hollick $=$ Koelreuteria viridifluminis (Hollick) Brown, n.comb.

Zizyphus longifolia Newberry=Zizyphus cinnamomoides Lesquereux.
THE RECOGNIZABLE SPECIES OF THE GREEN RIVER FLORA

Thallophyta :

Chlorellopsis coloniata Reis

Confervites mantiensis Bradley

Chroococcus? sp. cf. C. westii (W. West) P. Boye

Chroococcus? sp. cf. C. dispersus (Von Keissler) Lemmermar

Coelastrum? sp. cf. C. verrucosum Reinsch

Crinalium? sp. Bradley

Crinalium? sp. cf. C. endophyticum Crow

cf. Eremosphaera sp. De Bary

Hapalosiphon sp. cf. H. confervaceus Borzi

Microspora sp. cf. M. pachyderma (Wille) Lagerheim

Phacus sp. cf. P. caudata Hübner

Stigeoclonium? sp. cf. S. lubricum (Dillwyn) Kützing

Tetraedron sp. ef. T. regulare var torsum (Turner) Brunnthaler

Eoglobella longipes Bradley

Phenacocladus hendersoni Cockerell

Sphaerites, species of

Fungi, species of

Bryophyta: Lejeunea eophila Cockerell

Pteridophyta :

Acrostichum hesperium Newberry

Aneimia delicatula Brown

Asplenium eoligniticum Berry

Azolla berry Brown, n.sp.

Danaea coloradensis Knowlton

Lygodium kaulfussii Heer

Osmunda? sepulta (Newberry) Knowlton

Equisetum winchesteri Brown

Equisetum wyomingense Lesquereux

Spermatophyta:

Cycadipites sp. Wodehouse

Dioonipites sp. Wodehouse

Pinus ball Brown, n.sp.

Pinus scopulipites Wodehouse

Pinus strobipites Wodehouse

Pinus tuberculipites Wodehouse

Taxites eocenica Brown

Taxodium hiatipites Wodehouse

Glyptostrobus vacuipites Wodehouse

Picea grandivescipites Wodehouse

Picea pinifructus Brown

Abies concolipites Wodehouse

Abietipites antiquus Wodehouse

Cedripites eocenicus Wodehouse

Tsuga viridifluminipites Wodehouse

Cunninghamia concedipites Wodehouse

Ephedra eocenipites Wodehouse

Sparganium antiquum (Newberry) Berry

Sparganium eocenicum Brown

Potamogeton hollickipites Wodehouse

Potamogeton rubus Brown, n.sp.

Arundo pseudogoepperti Berry

Arundo reperta Lesquereux

Cyperacites haydenii (Lesquereux) Knowlton

Arecipites punctatus Wodehouse

Arecipites rugosus Wodehouse

Geonomites haydenii (Newberry) Knowlton

Sabalites florissanti (Lesquereux) Berry

Sabalites powellii (Newberry) Berry

Musophyllum complicatum Lesquereux

Peltandripites davisii Wodehouse

Smilacipites echinatus Wodehouse 
Spermatophyta-Continued.

Smilacipites herbaceoides Wodehouse

Smilacipites molloides Wodehouse

Populus wilmattae Cockerell

Salix cockerell Brown, n.sp.

Salix discoloripites Wodehouse

Salix longiacuminata Knowlton

Comptonia insignis (Lesquereux) Cockerell

Myrica minuta Knowlton

Myricipites dubius Wodehouse

Juglans alkalina Lesquereux

Juglans crossii Knowlton

Juglans nigripites Wodehouse

Juglans schimperi Lesquereux

Hicoria juglandiformis (Sternberg) Knowlton

Hicoria juxtaporites Wodehouse

Hicoria viridifluminipites Wodehouse

Engelhardtia corylipites Wodehouse

Alnus speciipites Wodehouse

Betula claripites Wodehouse

Betula coloradea Brown, n. name

Carpinus ancipites Wodehouse

Quercus castaneopsis Lesquereux

Quercus drymeja Unger

Quercus utensis Cockerell

Planera inequilateralis (Lesquereux) Knowlton

Planera nervosa Newberry

Celtis mecoshii Lesquereux

Momipites coryloides Wodehouse

Ficus mississipiensis (Lesquereux) Berry

Ficus omballi Brown

Ficus wyomingiana Lesquereux

Lomatia acutiloba Lesquereux

Lomatia coloradensis (Knowlton) Brown

Banksia comptonifolia Brown, n.sp.

Banksites lineatulus Cockerell

Oreodaphne coloradensis Brown, n.sp.

Oreodaphne lancifolia (Lesquereux) Brown, n.comb.

Oreodaphne viridiflumensis Knowlton

Liriodendron psilopites Wodehouse

Alsinites revelatus Cockerell

Sedum? hesperium Knowlton

Odostemon eocenia Brown, n.sp.

Liquidambar callarche Cockerell

Amygdalus gracilis Lesquereux

Potentilla? byrami Cockerell

Chrysobalanus lacustris Brown

Amorpha utensis Cockerell

Cassia hesperia Brown

Cercis tenuinervis (Lesquereux) Brown, n.comb.

Leguminosites lesquereuxiana (Knowlton) Brown, n.comb.

Mimosites coloradensis Knowlton

Podogonium americanum Lesquereux

Ailanthus lesquereuxi Cockerell

Ailanthipites berryi Wodehouse

Rhoipites bradleyi Wodehouse

Rhus balli Brown

Rhus longepetiolata (Lesquereux) Brown, n.comb.

Rhus variabilis (Newberry) Knowlton

Schmaltzia vexans (Lesquereux) Cockerell

Anacardites schinoloxus Brown

Anacardites schinus Brown, n.sp.

Celastrophyllum emarginatum Brown

Celastrophyllum lesquereuxii Brown

Maytenus berryi Brown

Acer lesquereuxii Knowlton

Thouinia eocenica Brown
Spermatophyta - Continued.

Talisiipites fischeri Wodehouse

Sapindus dentoni Lesquereux

Sapindus obtusifolius Lesquereux

Sapindus winchesteri Knowlton

Koelreuteria viridifluminis (Hollick) Brown, n.comb.

Dodonaea viscosoides Berry

Ilex coloradensis Brown; n.sp.

Zizyphus cinnamomoides Lesquereux

Parthenocissus tertiaria (Lesquereux) Knowlton

Vitipites dubius Wodehouse

Grewiopsis cissifolius Brown

Tilia crassipites Wodehouse

Tilia scudderi (Cockerell) Brown, n.comb.

Tilia tetraforaminipites Wodehouse

Tilia vescipites Wodehouse

Firmianites aterrimus Cockerell

Hibiscus roanensis Brown, n.sp.

Ochroma murata Brown, n.sp.

Sterculia coloradensis Brown

Ternstroemites viridiflumensis Brown

Eucalyptus? americana Lesquereux

Myriophyllum ambiguipites Wodehouse

Aralia wyomingensis Knowlton and Cockerell

Andromeda delicatula Lesquereux

Clethra? lepidioides Cockerell

Ericipites brevisulcatus Wodehouse

Ericipites longisulcatus Wodehouse

Fraxinus flexifolia (Lesquereux) Brown, n.comb.

Fraxinus wieser Brown, n.sp.

Syringa coloradea Brown, n.sp.

Apocynophyllum roanense Brown, n.sp.

Apocynophyllum wilcoxense Berry

Apocynospermum coloradensis Brown

Caprifoliipites viridifluminis Wodehouse

Sambucus? winchesteri Knowlton

Viburnum asperum Newberry

Menthites eocenicus Cockerell

Cucurbita glandulosa Brown

Achaenites cichorioides Knowlton

Phyllites ericoides Brown, n.sp.

Phyllites furcivena Brown, n.sp.

Phyllites glandiferus brown, n.sp.

Phyllites juncoides Brown

Phyllites ouratea Brown, n.sp.

Phyllites winchesteri Knowlton

Antholithes dubia Brown

Antholithes improbus Lesquereux

Antholithes pendula Brown

Antholithes polemonioides Brown

Antholithes vitaciflora Brown

Antholithes, species of

Carpolithus alabaccus Brown, n.sp.

Carpolithus caryophylloides Knowlton

Carpolithus cassioides Brown

Carpolithus filiferus Brown, n.sp.

Carpolithus insectoides Brown, n.sp.

Carpolithus paliuroides Brown, n.sp.

Carpolithus palmites Brown

Carpolithus prunoides Brown, n. name

Carpolithus serratifolius Brown

Carpolithus vitaceus Brown, n.sp.

Carpolithus, species of

Carpites inquirenda Knowlton

Carpites newberryanus Knowlton

Carpites viburni Lesquereux

Nordenskioldia borealis Heer 
Spermatophyta-Continued. Caulinites acanthus Brown Caulinites prehensus Brown

Rhizocaulon dichotomum Brown

Rhizocaulon natans Brown

\section{THE SIGNIFICANT SPECIES OF THE FLORA}

The flora of the Green River formation, like most fossil floras, contains species whose botanic affinities are not positively known. These species, although recognizable as entities and therefore sometimes of value as stratigraphic horizon markers, are not usually of much significance or help toward an interpretation of the environmental conditions of the region that produced and preserved the flora. After the species of doubtful affinity have been subordinated to their proper place in such an evaluation, the Green River flora shows many other species whose affinities are so clearly indicated that they can be compared, singly or in ecologic groups, with living species and groups. If the "law of uniformity", that the past must be understood in the light of the present, is applicable to biology as it is to physical geology, this comparison will give a general conception of the environment of the Green River flora.

Thallophyta: The Thallophyta, with the exception of Phenacscladus hendersoni Cockerell and the indefinite leaf-spot fungi included under Sphaerites, have been studied chiefly by Bradley. ${ }^{5}$ They are bacteria, spores of fungi, and algae. The bacteria, fungi, and non-reef-forming green and blue-green algae occur locally in beds of unusually rich oil shale and chert concretions in the middle and upper members of the Green River formation at localities that were near the center of the basin of deposition. The amount of organic matter in the oil shales decreases gradually to nothing shoreward. All the lithologic and structural evidence collected by Bradley suggests that the water in which the microfauna and microflora lived fluctuated periodically from a broad areal expanse with a central depth of 75 or 100 feet to residual, shallow, saline, stagnant ponds and pools.

The reef-forming algae occur principally in reefs in the shore phases of the basal member of the Green River formation. The reefs were formed at a time when the waters were clear, fresh, and stable-conditions in strong contrast with those under which subsequently the rich oil shales were deposited.

Bryophyta: Lejeunea eophila Cockerell is the only member of the Bryophyta yet identified from the Green River formation. It is of uncertain significance.

Pteridophyta: The Pteridophyta are represented by 7 ferns and 2 horsetails. Lygodium kaulfussii Heer

\footnotetext{
${ }^{5}$ Bradley, W. H., Algae reefs and oolites of the Green River forma. tion: U.S. Geol. Survey Prof. Paper 154, pp. 203-223, 1929 ; Origin and microfossils of the oil shale of the Green River formation of Colorado and Utah: U.S. Geol. Survey Prof. Paper 168, 1931.
}

is undoubtedly a climbing Lygodium. The Equisetums are true horsetails and indicate moist situations in thickets, on stream or lake shores, and in freshwater swamps. Azolla berry Brown, n.sp., may have had habits similar to living species of $A z o l l a$ that sometimes cover large surfaces on fresh, still waters.

Spermatophyta: Until recently the seed plants of the Green River flora have been known only from fossil remains of their flowers, fruits, and leaves. Now. with the studies of the fossil pollens initiated by Bradley and elaborated by Wodehouse, ${ }^{6}$ there is accumulating important, new evidence that helps to check many determinations of the megascopic remains. Wodehouse records pollen of 43 species, the names of which can be distinguished easily in the list of the recognizable species of the Green River flora (pp. $47-49)$ by the presence of the suffix "pites", signifying "pollen." Comparison of the pollen list with the list of megascopic elements reveals a number of differences that may be due to at least three factors. First, the pollen list is, according to Wodehouse, far from a complete representation of the flora. Second, the pollens identified are largely of the wind-transported kinds and undoubtedly include species from piants growing in localities so situated with respect to the area of deposition that no other remains of those plants would be likely to get into the fossil record. Such pollens from remote areas might be in serious discord with the rest of the flora in respect to climatic indications. Third, the oil shale containing the fossil pollens studied by Wodehouse came from the middle member of the Green River formation, which was deposited at a time when the lake waters were at a low stage, owing presumably to desiccation in a dry climate. The megascopic flora, on the other hand, came principally from the lower and upper members of the formation, which were deposited when the climate was moister. In consequence, the lower and upper floras are not greatly dissimilar, but they are somewhat different from the middle flora, which includes, for example, pollens of Ephedra, notably a dry-climate plant.

Gymnosperms: Wodehouse reports two cycads, $C y$ cadipites sp. and Dioonipites sp. No megascopic cycad remains have yet been identified in the Green River formation unless the fragment Danaea coloradensis Knowlton, described as a fertile fern pinnule, is a sporophyll of an extinct cycadlike plant. Pollens from 3 species of pine are recorded, Pinus scopulites, $P$. strobipites, and $P$. tuberculipites, whereas the only megascopic remains of Pinus are a 3-needled cluster, Pinus ball Brown, n.sp., and pieces of undescribed fossil wood. Picea grandivescipites may be pollen

${ }^{6}$ Wodehouse, R. I', Tertiary pollen, 1 , Pollen of the living representatives of the Green River flora: 'Torrey Bot. Club Bull., vol. 59, pp. 313-340, pls. 20-22, 1932 ; Tertiary pollen, 2, The oil shules of the Eocene Green River formation: Idem, vol. 60, pp. 479-524, 1933 , 
from the same species of spruce that produced the seed Picea pinifructus Brown. The only other large gymnospermous object yet identified is the leaf Taxites eocenica Brown. This may have come from one of the remaining gymnospermous plants identified by Wodehouse from their pollen as Taxodium hiatipites, Glyptostrobus vacuipites, Abies concolipites, Abietipites antiquus, Cedripites eocenicus, Tsuga viridifluminipites, and Cunninghamia concedipites. Ephedra cocenipites is a unique pollen not yet supported by megascopic remains from the Green River formation.

Angiosperms: Monocotyledons-Wodehouse's Potamogeton hollickipites is corroborated by a fruiting head, Potamogeton mubus Brown, n.sp. Arundo pseudogoepperti Berry, A. reperta Lesquereux, and Cyperacites haydenii (Lesquereux) Knowlton look like fragments of grass or sedge leaves, but no distinctive significance can be attached to them. Wodehouse lists 2 palms, Arecipites punctatus and A. rugosus, whereas there are 3 species known from foliage remains, Geonomites haydenii (Newberry) Knowlton, Sabalites florissanti (Lesquereux) Berry, and S. powellii (Newberry) Berry, and 1 probable seed, Carpolithus palmites Brown, n.sp. Musophyllum complicatum Lesquereux, while recognizable as a fossil species, is of doubtful identity. Peltandripites davisii, Smilacipites echinatus, S. herbaceoides, and S. molloides, reported by Wodehouse, are not represented by other remains.

Dicotyledons: The willows are represented by 1 pollen species, Satix discoloripites, and 2 leaf species, S. cockerell Brown, n.sp., and S. longiacuminata Knowlton. Wodehouse reports Myricipites dubius; the Myricaceae are otherwise represented by Comptonia insignis (Lesquereux) Cockerell and Myrica minuta Knowlton, but I regard the last two and especially the Comptonia as of doubtful identity. Wodehouse has 1 walnut pollen, Juglans nigripites. whereas the leaf remains suggest 3 species, $J$. alkalina Lesquereux, J. crossii Knowlton, and J. schimperi Lesquereux. There are 2 hickory pollens, Hicoria juxtaporites and $H$. viridifluminipites, but only 1 leaf, H. juglandiformis (Sternberg) Knowlton, has been identified. In addition to the foregoing species, the .Tuglandaceae are further represented, according to Wodehouse, by the pollen species, Engelhardtia corylipites. To support the evidence of the betulaceous pollens, Alnus speciipites, Betula claripites, and Carpinus ancipites, there is one leaf species, Betula coloradea Brown, n. name, which apparently falls within this group. The Ulmaceae contribute 1 pollen, Momipites coryloides, and 3 leaves, Celtis mocoshii Lesquereux, Planera inequilateratis (Lesquereux) Knowlton, and $P$. nervosa Newberry. The Magnoliaceae are represented by the pollen Liriodendron psitopites but not yet by any other remains. Ailanthus is represented with certainty by the pollen Ailanthipites berryi and the seed Ailanthus lesquereuxi Cockerell; but no undoubted Ailanthus leaves have been identified. Wodehouse identifies 1 sumac pollen, Rhoipites bradleyi; this is in contrast to 4 leaf species, Rhus balli Brown, $R$. longepetiolata (Lesquereux) Brown, n.comb., $R$. variabilis (Newberry) Knowlton, and Schmaltzia vexans (Lesquereux) Cockerell, and 2 seeds, Anacardites schinoloxus Brown and A. schinus Brown, n.sp. A species of sapindaceous pollen, Talisiipites fischeri, may be related to the leaf, Thouinia eocenica Brown; and five other leaf and fruit species of Sapindaceae are reported to be present-Sapindus dentoni Lesquereux, S. obtusifolius Lesquereux, S. winchesteri Knowlton, Dodonaea viscosoides Berry, Koelreuteria viridifluminis (Hollick) Brown, n.comb. Wodehouse recognizes 1 fossil pollen of the Vitaceae, Vitipites dubius, but discredits its having any relation to the leaf, Parthenocissus tertiaria (Lesquereux) Knowlton. The presence of some member or members of the Vitaceae seems to be further attested by a flower, Antholithes vitaciflora Brown; a seed, Carpolithus vitaceus Brown, n.sp.; and a tendril, Caulinites prehensus Brown. The lindens are represented by the 3 pollens Titia crassipites, T. tetraforaminipites, and $T$. vescipites, and by 1 leaf, T. scudderi (Cockerell) Brown, n.comb. The only pollen representative of the family Haloragidaceae is Myriophyllum ambiguipites, which is unmatched by megascopic remains. Wodehouse reports 2 pollen species of Ericaceae, Ericipites brevisulcatus and $E$. longisulcatus, but will not ally them with Andromeda delicatula Lesquereux or Clethra? lepidioides Cockerell. The leaf Phyllites ericoides Brown, n.sp., though suggestive of ericaceous affinity, is actually of uncertain identity. The fossil pollen Caprifoliipites viridifluminis is regarded by Wodehouse as a generalized type and may not belong to the Caprifoliaceae; nevertheless the probability that it does so belong is strengthened by the presence of a flower, Sambucus? winchesteri Knowlton, a seed, Carpites viburni Lesquereux, and a leaf, Viburnum. asperum Newberry.

In addition to the species already reviewed there remain a few that have been identified rather clearly on the basis of leaves or fruits, but are not represented by pollens in Wodehouse's list. The bur-reed family, Sparganiaceae, supplies the species Sparganium antiquum (Newberry) Berry. No Populus pollen is listed, but the leaf Poputus wilmattae Cockerell has the appearance of authenticity, except that it also strongly resembles some of the American Cretaceous and Tertiary forms variously called Populus, Grevia, Grewiopsis and Trochodendroides. The evidence for calling many of these Cercidiphyllum is strong, but thus far no characteristic seeds have been found. It seems 
strange that no oak pollen has been found, whereas three species of leaves have been identified, Quercus castaneopsis Lesquereux, Q. drymeja Unger, and $Q$. utensis Cockerell. These, of course, may be wrongly assigned to Quercus. Ficus omballi Brown, with its characteristic intramarginal vein is figlike, but it also suggests apocynaceous affinities. The seed Banksites lineatulus Cockerell and the leaves Lomatia coloradensis (Knowlton) Brown and Banksia comptonifotia Brown, n.sp., indicate the presence of Proteaceae in the Green River flora. The Lauraceae are represented by 3 described species of Oreodaphne, 1 of which, $O$. coloradensis Brown, n.sp., seems to be correctly assigned, at least to the family. Odostemon eocenia Brown, n.sp., is clearly a barberry. Liquidambar is identified with certainty on the basis of both leaves and fruit. The legumes are represented by a number of different leaves and fruits, but their exact reference is conjectural. The maple leaf Acer lesquereuxi Knowlton is not yet supported by fruits of the characteristic samara type. The variable leaves of $Z i z y$ phus cinnamomoides Lesquereux may represent Zizyphus or some other related rhamnaceous form. The leaves called Eucalyptus? americana Lesquereux are readily identifiable, but no fossil Eucalyptus fruits have yet appeared to confirm the identification, and the leaves may therefore represent some other genus and family, possibly some apocynaceous form. The Apocynaceae are assumed to be present in the Green River flora on the basis of several kinds of leaves and one fruit, Apocynospermum coloradensis Brown. The leaves called Aratia wyomingensis Knowlton and Cockerell are distinctive objects, but their botanic assignment seems a little doubtful to me. Fraxinus flexifotia (Lesquereux) Brown, n.comb., and $F$. wieser Brown, n.sp., may be ashes but no Frawinus fruits have yet been identified.

The Green River formation locally contains silicified logs, some of which are covered with fossil algae. These fossil woods represent both gymnosperms and angiosperms, but they have not yet been studied in sufficient detail to warrant publication of more than this brief note of their existence.

The remainder of the leaf, flower, fruit, and other fossil fragments not mentioned in the foregoing discussion constitutes a reservoir of more or less recognizable objects from which as more collections accumulate, evidence may be drawn to support and make certain the identification of species now considered doubtful or only partially characterized.

This survey of the Green River flora shows that the species that may be regarded as correctly allocated botanically and as indicative of climate, latitude, altitude, soils, insolation, and general ecology substantiate previously expressed opinions that this flora inhabited a warm-temperate region that was $58868-34-2$ sometimes dry and sometimes well watered. The ecologic group of species comprising Hicoria, Juglans, Liquidambar, Aitanthus, and Titia, if judged by its modern equivalent, suggests that the Green River flora, with the exception of some conifers, grew at an altitude above sea level of probably not more than 3,000 feet and very likely at a considerably lower level. The Green River formation, now from 5,000 to 10,000 feet above the sea, must therefore have been uplifted several thousand feet since the deposition of the sediments that contain the fossil flora.

It is too premature to state definitely what changes there were in the flora of the Green River formation basins between early and late Green River time. That statement waits upon further collections and study.

\section{SYSTEMATIC DESCRIPTIONS}

RHODOMELACEAE

Phenacocladus hendersoni Cockerell

Plate 8 , figure 1

Phenacocladus hendersoni Cockerell, Torreya, vol. 26, no. 6 . p. 111, fig. on p. 112, 1926.

The specimen figured here agrees with the types described and figured by Cockerell, but the details are not as clear as in those specimens. Cockerell assigned this species provisionally to the marine algae, Rhodomelaceae. That it belongs to this family seems only remotely probable to me. It may not even be an alga, but something in an entirely different group, as, for example, a species of fine-leaved Myriophyllum or Utricularia. Whatever these objects represent they can at least be recognized easily.

Occurrence: On Parachute Creek, 10 miles north of Grand Valley, Colo.

Figured specimen in United States National Museum.

\section{SFHAERIACEAE}

Sphaerites, species of

Spheria myricae Lesquereux, U.S. Geol. and Geog. Survey Terr. Ann. Rept. for 1872 , p. 390,1873 ; U.S. Geol. Survey Terr. Rept., vol. 7, p. 34, pl. 1, fig. 4, 1878.

sphaerites myricae Lesquereux. Meschinelli, Sylloge fungorum fossilium, p. 23, 1892.

Caenomyces encalyptae Knowlton, U.S. Geol. Survey Prcf. Paper 131, p. 148, pl. 36, figs. $8,9,1923$.

Caenomyces sapindicola Knowlton, idem, p. 148, pl. 36, fig. 10 Caenomyces planerae Brown, U.S. Geol. Survey Prof. Paper 154, p. 281, 1929.

Inasmuch as the supposed leaf-spot fungi listed in the synonymy cannot, as the authors admit, be distinguished from one another, I propose to group these spots on specimens from the Green River formation under one designation. I do not see how the multiplication of species of this sort helps the progress of paleobotany. 
Undoubtedly leaf-spot fungi on species of living Myrica, Eucalyptus, Sapindus, and Planera might be identified as individual species. With respect to indistinguishable fossil forms, however, there is no argument except inference for distinction of species. Such inferences, it seems to me, are pertinent in the discussion of each new occurrence, but they do not justify the cluttering up of paleobotanic literature with nonselective names.

\section{POLYPODIACEAE}

\section{Asplenium eoligniticum Berry}

Plate 8 , figures 3,4

Asplenium eoligniticum Berry, U.S. Geol. Survey Prof. Paper 165, p. 62 , pl. 8 , figs. 2-4, 1930 . (See synonymy and discussion.)

The fragments figured here seem to represent the species described by Berry from deposits of about the same age in the Wind River Basin of Wyoming. These specimens show a strong midrib and numerous more or less closely spaced veins, most of which fork near the midrib. The margin is irregularly serrate. In the absence of sori it is difficult to assign such specimens to a specific genus.

Occurrence: Clear Creek, sec. 33, T. 4 S., R. 100 W., 35 miles northwest of De Beque, Colo. (fig. 3) ; first ridge south of Ute Trail, Roan Plateau, 30 miles northwest of De Beque, Colo. (fig. 4).

Figured specimens in United States National Museum.

\section{SALVINIACEAE}

Azolla berry Brown, n.sp.

Plate 8 , figure 2

This specimen does not show any clearly defined fruiting bodies, sporocarps, but the form and foliage are characteristic of Azolla. The plant is a pinnately branched irregular stem 3 centimeters long with branches 0.5 centimeter long covered with small imbricated, 2'-lobed, elliptic leaves less than 1 millimeter long. Filaments that appear to be rootlets are faintly discernible along the stem. Darker portions on the leaves may represent fruiting bodies, but these are indefinite. This species can be compared with the living $A$. filiculoides Lamarck, which ranges from California to Chile. Azolla is a genus of floating pteridophytes inhabiting still, fresh waters, sometimes eovering large surfaces. There are five species of wide geographic distribution.

This is the earliest known Azo la. Berry ${ }^{7}$ has described Azolla tertiaria from the upper Miocene Esmeralda formation near Hawthorne, Nev.

7 Berry, E. W., The flora of the Esmeralda formation in western Nevada : U.S. Nat. Mus. Proc., vol. 72 , art. 23 , p. 4, pl. 1, figs. 9,10 , 1927.
Occurrence: On east point of first ridge south of Ute Trail, Roan Plateau, 30 miles northwest of De Beque, Colo.

Type in United States National Museum. Named for Prof. E. W. Berry, of the Johns Hopkins University.

\section{MARATTIACEAE}

Danaea coloradensis Knowlton

Danaea coloradensis Knowlton, U.S. Geol. Survey Prof. Paper 131, p. 150, pl. 36, fig. 4, 1923.

Although Knowlton rather confidently referred this fragment to Danaea in 1923, by 1924 he seemed to have doubts, agreeing, however, with Berry ${ }^{8}$ that certain specimens of Green River age from the Wind River Basin of Wyoming, described by Cockerell, ${ }^{\text {? }}$ were the same species, but not Ophioglossum. To this Cockerell ${ }^{10}$ replied, admitting that his specimen was not an Ophioglossum; that, however, it was also not a Danaea; that Danaea coloradensis was apparently a different thing and, in the absence of proof to the contrary, is to be retained in Danaea; and that Knowlton had recognized a similarity of Cockerell's specimen to a problematic organism described but not figured by Ward ${ }^{11}$ from the Fort Union formation near Glendive, Mont., calling it Xantholithes propheticus. Cockerell admitted the congeneric affinity of his specimen with Ward's and renamed his specimen $X$ antholithes hastatiformis, at the same time intimating his opinion that the object was an alga belonging to an extinct family. In 1930 Berry ${ }^{12}$ reviewed the whole matter and suggested that all these specimens might be cycadaceous sporophylls belonging to some member of the Williamsoniales and resembling similar remains called Williamsonia marylandica from the Magothy formation of Maryland. ${ }^{13}$

Although there are points of resemblance between Danaea coloradensis Knowlton and the other specimens here discussed, I am disposed to agree with Cockerell that there are differences significant enough to arouse doubts concerning relationship. It seems best to maintain the status of Danaea coloradensis Knowlton until completer material is found. In spite of the admittedly doubtful biological assignment of this fossil, there is no question that it constitutes unique and recognizable material.

${ }^{8}$ Berry, E. W., Ophioglossum hastatiforme Ckl. not an Ophiogossum Torreya, vol. 24 , no. 3 , p. $49,1924$.

9. Cockerell, T. D. A., A genuine fossil Ophioglossum: Torreya, vol. 24 no. 1, p. 10 , with text fig., 1924.

${ }_{10}$ Cockerell, T. D. A., The supposed fossil ophioglossum: Torreya, vol. 26 , no. 1, p. 10,1926

11 Ward, L. F., Remarks on an undescribed vegetable organism from the Fort Union group of Montana: Am. Assoc. Adv. Sci. Proc., vol. 37, pp. 199-201, 18s9; Glimpses of the cosmos, vol. 4, p. 150, 1915.

12 Berry, E. W., A flora of Green River age in the Wind River Basin of Wyoming: U.S. Geol. Survey Prof. Paper 165, p. 78, 1930.

${ }^{13}$ Berry, E. W., Upper Cretaceous, p. 769 , pl. 51, figs. 5, 6, Maryland Geol. Survey, 1916. 


\section{PINACEAE}

\section{Pinus ball Brown, n.sp.}

Plate 8, figure 5

The only record of Pinus from the Green River formation, with the exception of pollen grains, is this 3-needled cluster. The leaves are 2.5 centimeters long, are recurved slightly, and are held together loosely at the base. The sheath is lacking. Modern pines with deciduous sheaths include the soft pines and one pitch pine, $P$. chihuahuana. Of the soft pines, the group of piñons or nut pines, $P$. parryana, $P$. cembroides, and $P$. edulis, is characterized by having deciduous-sheathed 2- to 4-needled clusters. This fossil species may therefore belong to the piñon group of pines.

Occurrence: Between Carr and Brush Creeks, 30 miles northwest of De Beque, Colo.

Type at the Agricultural and Mechanical College of Texas, College Station, Tex. Named for Prof. O. M. Ball.

\section{SPARGANIACEAE}

\section{Sparganium antiquum (Newberry) Berry}

Brasenia? antiqua Newberry, U.S. Nat. Mus. Proc., vol. 5, p. 514, 1882; U.S. Geol. Survey Mon. 35, p. 93, pl. 68, fig. 7, 1898.

Pontederites hesperia Knowlton, U.S. Geol. Survey Prof. Paper 131, p. 154, pl. 36, fig. 6, 1923.

Sparganium antiquum (Newberry) Berry, Bot. Gaz., vol. 78, pp. 342-348, figs. 1-7, 1924; U.S. Geol. Survey Prof. Paper 165, p. 64, p. 65, fig. 5; pl. 8, fig. 5, 1930.

Pontederites thecoides Hollick, Torrey Bot. Club Bull., vol. 56, p. 94 , pl. 2, fig. 1, 1929.

The venation and general form of Pontederites thecoides Hollick are identical with those of $P$. hesperia Knowlton, which Berry has called Sparganium antiquum.

\section{POTAMOGETONACEAE}

Potamogeton rubus Brown, n.sp.

Plate 8 , figure 6

The specimen shows a head of aggregated nutlets having the outline and habit of modern Potamogetons. This head is 1 centimeter long, elongated rather than globular, and is composed of a dozen or more nutlets. These nutlets are lobed and show the apical protuberance characteristic of potamogetons.

Occurrence: Cliff on east side of Carr Creek, 3 miles above Highmore, Colo.

Type in United States National Museum.

\section{GRAMINEAE}

\section{Arundo reperta Lesquereux}

Arundo reperta Lesquereux, U.S. Geol. and Geog. Survey Terr. Bull., vol. 1, p. 384, 1875 [1876] ; idem, Ann. Rept. for 1874 , p. 311, 1876 ; U. S. Geol. Survey Terr. Rept., vol. 7, p. 87, pl. 8, figs. 6-8, 1878.

Knowlton, U.S. Geol. Survey Prof. Paper 131, p. 152, 1923.
Knowlton discussed the status of this species and admitted its unsatisfactory diagnostic characters. The feature that seems to justify its retention as a species is the cluster of seeds shown in Lesquereux's figure 6 . These seeds may or may not have had any organic connection with the "stem" or "leaf" on which they now lie. This "stem" or "leaf" is similar to that identified as Arundo goepperti, now called Arundo pseudogoepperti Berry. ${ }^{14}$ Knowlton on page 140 first rejected this species from the Green River flora and then on page 143 regarded it as possibly identical with Arundo reperta. If the name $A$. reperta were restricted to the seeds and $A$. pseudogoepperti to the "stems" or "leaves" the difficulty would be resolved. Indefinite as these remains may be biologically, they nevertheless can be reeognized as fossils and can be assigned to the above makeshift species.

\section{SALICACEAE}

\section{Salix cockerell Brown, n.sp.}

Plate 9, figures $6-10$

These well-preserved linear-lanceolate leaves range in length from 10 to 15 centimeters and in width from 2 to 3 centimeters. The apex is acute and the base cuneate to rounded. The petiole is relatively short and thick. The teeth of the finely serrate margin are minutely glandular. A strong midrib divides the leaf symmetrically. The secondaries are numerous, more or less uniformly spaced, and camptodrome. Between the prominent secondaries appear minor, shorter intermediaries, which fail to reach as far as the margin.

Except that this species has a more elongate form and more numerous secondaries, it might well be identical with Salix inquirenda Knowlton, ${ }^{15}$ now, however, regarded as a poplar by Berry. ${ }^{16}$ It may also be compared with Salix varians Goeppert and Salix schimperi Lesquereux, from the Mascall and Cherry Creek beds respectively in the John Day Basin, Oreg. The distinction of willows from poplars on the basis of leaf remains alone is admittedly difficult and often impossible. Salix cockerell is remarkably like a number of living American willows but particularly like S. Zasiandra Bentham, of the western United States.

Occurrence: Head of Salt Wash, Roan Plateau, 30 miles northwest of De Beque, Colo.

Types (except fig. 10, which is at the University of Colorado) in the United States National Museum. Named for Prof. T. D. A. Cockerell.

${ }^{14}$ Berry, E. W., The Upper Cretaceous and Eocene floras of South Carolina and Georgia: U.S. Geol. Survey Prof. Paper 84, p. 134, pl. 24, fig. $7,1914$.

${ }^{15}$ Knowlton, F. H., Flora of the Latah formation: U.S. Geol. Survey Prof. Paper 140, p. 32, p1. 11, figs. 1, 2, 1926.

${ }^{16}$ Berry, E. W., A Miocene flora from Grand Coulee, Wash. : U.S. Geol. Survey Prof. Paper 170, p. 35, 1931. 


\section{Salix longiacuminata Knowlton}

Plate 8 , figures 7,8

Salix longiacuminata Knowlton, U.S. Geol. Survey Prof. Paper 131, p. 155, 1923.

Myrica sp. Knowlton, idem, p. 158, pl. 40, fig. 13.

Banksia cockerelli Brown, U.S. Geol. Survey Prof. Paper 154, p. 286, pl. 72, fig. 7, 1929 .

Knowlton's description of this species was not accompanied by illustrations, but in the collections of the United States National Museum I found a specimen that he had marked for illustration. It checks with the description and is undoubtedly the type on which the description was based. In 1929 I described a leaf as Banksia cockerelli which I now find is identical with Salix longiacuminata. Knowlton's Myrica sp. also belongs here.

Occurrence: On Clear Creek, sec. 33, T. 4 S., R. 100 W., 30 miles northwest of De Beque, Colo.

Type and figured specimens in United States National Museum.

\section{MYRICACEAE}

\section{Myrica minuta Knowlton}

Plate 9, figures 1, 2

Myrica minuta Knowlton, U.S. Geol. Survey Prof. Paper 131, p. 157 , pl. 37, fig. $12,1923$.

Salix linearis Knowlton, idem, p. 155, pl. 37, fig. 8.

These portions of twigs bear the leaves of Myrica minuta. In the axils of the leaves are buds or fruits, but their details cannot be clearly distinguished. Better material will throw much-needed light on the status and relationship of those forms in the Green River and Florissant floras called Myrica, Planera, Ulmus, and Fagopsis. Knowlton's Salix linearis is a large leaf of Myrica minuta.

Myrica minuta has sharp serrate teeth and can be distinguished by this character from the small leaves of Planera nervosa, which has crenate rounded teeth. Myrica minuta so closely resembles the small leaves of Myrica drymeja of the Florissant lake beds that I hesitate to draw distinctions between the two species. Some of its larger leaves are like those of Rhus variabilis, but they can be segregated by the fact that the former has a regular secondary undivided vein for each marginal tooth, whereas the latter has an irreguJar vein for each tooth and that vein usually forks, sending branches to subsidiary teeth. The latter species also has conspicuous intermediary secondary veins that appear to run into the notches between the teeth lut that divide near the notch, sending one branch above and the other below the notch.

Occurrence: Head of Kimball Creek, 30 miles northwest of De Beque, Colo.

Figured specimens in the Uaited States National Museum.

\section{Comptonia insignis (Lesquereux) Cockerell}

Myrica insignis Lesquereux, U.S. Geol. Survey Terr. Rept., vol. 7, p. 135, pl. 65, figs. 7, 8, 1878.

Myrica alkalina Lesquereux, U.S. Geol. Survey Terr. Rept.. vol. 8, p. 149, pl. 65-A, figs. 10-15, 1883.

Comptonia insignis Cockerell, Colorado Univ. Studies, vol. 3, p. 173, 1906; Am. Mus. Nat. Hist. Bull., vol. 24, p. 81 , 1908.

Berry, Am. Naturalist, vol. 40, p. 499, 1906.

Lesquereux's species Myrica alkatina was included with Comptonia insignis, from Florissant, by Berry in 1906. A study of the types now included under Comptonia insignis suggests to me the variable leaflets of Koelreuteria and Dipterodendron rather than Comptonia. Further, I am not so certain that Myrica alkalina should be included with Comptonia insignis.

\section{JUGLANDACEAE}

\section{Juglans alkalina Lesquereux}

Juglans alkalina Lesquereux, U.S. Geol. and Geog. Survey Terr. Bull., vol. 1, p. 382, 1875 [1876] ; Ann. Rept. for 1874 , p. 308,1876 ; U.S. Geol. Survey Terr. Rept., vol. 7. p. 288 , pl. 62 , figs. $6-9,1878$.

I'icus alkalina Lesquereux, U.S. Geol. Survey Terr. Rept., vol. 8, p. 164, pl. 44, figs. 7-9, 1883.

Juglans winchesteri Knowlton, U.S. Geol. Survey Prof. Paper 131, p. 160, pl. 38, fig. 5, 1923.

Ficus alkatina Lesquereux, from the same locality as Juglans alkatina Lesquereux, was, however, not included in the Green River flora by Knowlton. On examination of the type specimens I find that both species are identical. The leaf described by Knowlton as Juglans winchesteri resembles $J$. alkatina so closely that I hesitate to draw a distinction between them. The only apparent difference is the unusually thick petiole in $J$. winchesteri, but this feature may well be an abnormality or a peculiarity due to fossilization.

\section{Juglans schimperi Lesquereux}

Jugians schimperi Lesquereux, U.S. Geol. and Geog. Survey Terr. Ann. Rept. for 1871, Suppl., p. 8, 1872; U.S. Geol. Survey Terr. Rept., vol. 7, p. 287, pl. 56, figs. 5-10, 1878.

Juglans occidentalis Newberry, U.S. Nat. Mus. Proc., vol. 5, p. 507, 1882 [1883] ; U.S. Geol. Survey Mon. 35, p. 34, pl. 65, fig. 1 ; pl. 66 , figs. $1-4,1898$.

Ficus ungeri Lesquereux, U.S. Geol. and Geog. Survey Terr. Ann. Rept. for 1871, Suppl., p. 7, 1872; U.S. Geol. Survey Terr. Rept., vol. 7 , p. 195 , pl. 30 , fig. 3 , 1878; vol. 8 , p. 163, pl. 44, figs. 1-3, 1883.

The types as well as other specimens of the disputed species listed in the synonymy are before me. Knowlton ${ }^{17}$ attempted to segregate the first two species, but I confess inability to follow him in the presence of the

${ }^{17}$ Knowlton, F. H., Revision of the flora of the Green River forma tion: U.S. Geol. Survey Prof. Paper 131, pp. 158-160, 1923. 
actual specimens. If extremes of variation were selected, even in the leaves of a living species, several instead of one species might be distinguished. Similarly a comparison of Lesquereux's figure 5 (vol. 7, pl. 56) of Juglans schimperi and his figure 3 (vol. 7, pl.30) of Ficus ungeri would seem to justify the designation of two species. However, between these two extremes there is a series of specimens that clearly. links them together. What, for example, distinguishes Newberry's figure 4 (Mon. 35, pl. 66) of Juglans occidentalis from Lesquereux's figure 6 (vol. 7, pl. 56) of J. schimperi and both these from Lesquereux's figure 1 (vol. 8, pl. 44) of Ficus ungeri? Of the Juglans species Knowlton says: "The only way of distinguishing them is by the long, narrow, sharp-pointed leaflets with a round equal-sided base and slightly more acute-angled secondaries in Juglans schimperi, and the broader, less acuminate leaflets with unequalsided base and very low-angled secondaries in Juglans occidentalis." Using the distinction between the acute and blunt apex, how shall Lesquereux's figure 5 (vol. 7, pl. 56) of J. schimperi be separated from Newberry's figure 1 (Mon. 35, pl. 65) of J.occidentalis? So far as the equal or unequal sided base is concerned, why did Knowlton retain both Newberry's figures 2 and 4 (Mon. 35, pl. 66) under J. occidentalis? Lesquereux's figures of Ficus ungeri represent large specimens, with the exception of figure 2 (vol. 8, pl. 44). How shall that basal fragment be separated from the similar base of Newberry's figure 4 (Mon. 35, pl. 66) of Juglans occidentatis? The conclusion which this comparison suggests is that all the species listed in the synonymy are but a single species with the usual great variation in foliage that should be expected. It must be emphasized that in this discussion I have confined myself to specimens from the Green River formation and have not attempted to dispose of specimens from other formations cited in the synonymy of Knowlton's paper or in the general literature.

One other species in the Green River flora, Ficus omballi Brown, ${ }^{18}$ which might be compared with Juglans schimperi, needs to be commented on here. The figure of that species, unfortunately, is not clear, but there is sufficient detail to show that the secondary veins are not broadly camptodrome near the margin, as they are in J. schimperi, but are curved upward very abruptly into loops that unite to form a conspicuous, slightly irregular, intramarginal vein. This leaf, as stated in the description, resembles certain living species of Ficus; but it is also remarkably like some species of Asclepiadaceae and Apocynaceae.

\footnotetext{
${ }^{18}$ Brown, R. W., Additions to the flora of the Green River forma
} tion: U.S. Geol. Survey Prof, Paper 154, p. 285, pl. 72, fig. 2, 1929 ,
BETULACEAE

Betula coloradea Brown, n. name

Betula eocenica Brown, U.S. Geol. Survey Prof. Paper 154. p. 283 , pl. 71 , fig. 6,1929 . Not the same as $B$. eocenica Ettingshausen, K. Akad. Wiss. Wien Sitzungsber., vol. 28 , p. 518, pl. 1, fig. $1,1858$.

No new specimens of this species have appeared in recent collections. There is a possibility that Grewiopsis cissifolius Brown ${ }^{19}$ may be a large form of $B$. cotoradea.

\section{FAGACEAE}

\section{Quercus castaneopsis Lesquereux}

Quercus castaneopsis Lesquereux, U.S. Geol. Survey Terr. Rept., vol. 8, p. 155, pl. 28, fig. 10, 1883.

Quercus castanoides Newberry, U.S. Nat. Mus. Proc., vol. 5. p. 506 , 1883 ; U.S. Geol. Survey Mon. 35 , p. 70, pl. 65, fig. $6,1898$.

Ilex? affinis Lesquereux, U.S. Geol. and Geog. Survey Terr. Ann. Rept. for 1871, Suppl., p. 8, 1872 ; U.S. Geol. Survey Terr. Rept., vol. 7, p. 270, pl. 50, figs. 2, 3, 1878.

Ilex maculata Lesquereux, U.S. Geol. Survey Terr. Rept., vol. 8, p. 186, pl. 44, fig. 5, 1883.

The specimens on which the Ilex species of the synonomy were based are fragmentary, but their texture, venation, and marginal dentition where preserved indicate that they are small leaves of Quercus castaneopsis. The specific designation affinis, being preempted, cannot be used with Quercus.

\section{Quercus drymeja Unger \\ Plate 8 , figure 9}

Quercus drymeja Unger, Chloris protogaea, p. 113, nl. 32, figs. $1-4,1847$.

Lesquereux, U.S. Geol. Survey Terr. Rept., vol, 8, p. 154, pl. 28, fig. 12, 1883 .

The specimen figured is a linear leaf with few large hooked teeth on the margin. Few secondary veins curve gently from the midrib into the teeth. Finer venation obscure.

Knowlton did not include this species in his Revision of the Flora of the Green River Formation, although he included Quercus castaneopsis Lesquereux. ${ }^{20}$ Both species have a typical Green River matrix. The possibility that these specimens represent the species described by Unger from the Miocene of southern Europe is perhaps remote.

Occurrence: Head of Kimball Creek, 30 miles northwest of De Beque, Colo.

Figured specimen in United States National Museum.

19 Brown $R$. W. Additions to the flora of the Green River formation: U.S. Geol. Survey Prof. Paper 154:, p. 290, pl. 74, fig. 8, 1929.

${ }^{20}$ Lesquereux, Leo, The Cretaceous and Tertiary floras: U.S. Geol. Survey 'Terr. Rept., vol. 8, p. 155 , pl. 28, fig. 10, 1883. 


\section{ULMACEAE}

\section{Planera inequilateralis (Lesquereux) Knowlton}

Alnites inaequilateralis Lesquereux, U.S. Geol. and Geog. Survey Terr. Bull, vol. 1, p. 381, 1875 [1876]; Ann. Rept. for 1874 , p. 307,1876 ; U.S. Geol. Survey Terr. Rept., vol. 7 , p. 141 , pl. 62 , figs. $1-4,1878$.

Alnus inaequilateralis Lesquereux, U.S. Geol. Survey Terr. Rept., vol. 8, p. 151, 1883.

Planera variabilis Newberry, U.S. Nat. Mus. Proc., vol. 5, p. 508, 1882 [1883] ; U.S. Geol. Survey Mon. 35, p. 83, pl. 66 , figs. 5, 6 [not fig. 7 , which is Rhus variabilis (Newberry) Knowlton], 1898.

Pianera inaequilateralis (Lesquereux) Knowlton, U.S. Geol. Survey Prof. Paper 131, p. 161, 1923.

Comptonia? anomala Knowlton, idem, p. 158, pl. 37, fig. 1 .

The investigators who have handled these fossils have expressed doubts as to the validity of the classifications they made. The student latest to express an opinion is Berry, who suggests that Newberry's figure 5 , but not figures 6 and 7 (Mon. 35), is synonymous with his new species, Grewiopsis wyomingensis Berry. ${ }^{21}$ Reference to Berry's figures shows that his new specimens are equilateral leaves. Newberry's figure 5 , however, represents a markedly inequilateral specimen whose venation and marginal dentition are inlike those of Grewiopsis wyomingensis.

The asymmetry of these specimens suggests an alternative to their being Planera-namely, that they may be leaflets of some compound leaf like that of the box elder, Acer negundo, which exhibits many variable forms.

\section{Planera nervosa Newberry}

Pianera ne vosa Newberry, U.S. Nat. Mus. Proc., vol. 5, p. 508, 1882 ; U.S. Geol. Survey Mon. 35, p. 83, pl. 67, figs. 2, 3, 1898.

Myrica praedrymeja Knowlton, U.S. Geol. Survey Prof. Paper 131, p. 157, pl. 36, figs. 1-3, 1923.

Salix sp. Knowlton, idem, p. 156, pl. 37, figs. 3, 5.

Dalbergia viridiflumensis Knowlton, idem, p. 164, pl. 40, fig. 10.

An examination of the type specimens of the last three species cited in the synonymy shows that in venation, form, and texture they agree with the types of Planera nervosa. This species can be distinguished from Myrica minuta Knowlton by its rounded crenate teeth, which are in strong contrast with the pointed serrate teeth of the latter species.

\section{Celtis mecoshii Lesquereux}

Celtis mccoshii Lesquereux, U.S. Geol. Survey Terr. Rept., vol. 8, p. 163, pl. 38, figs. 7, 8, 1883.

Celtis debequensis Brown, U.S. Geol. Survey Prof. Paper 154, p. 284, pl. 72, fig. 1, 1929.

Lesquereux's figure 7 is based on a specimen that has a Green River matrix and is undoubtedly the material he listed as coming from Randolph County

${ }^{21}$ Berry, E. W., A flora of Green River age in the Wind River Basin of Wyoming: U.S. Geol. Survey Prof. Paper 165, p. 73, pl. 8, fig. 6 ; pl. 13, figs. 1, 2, 1930. (now Uinta County), Wyo. Knowlton did not include this species in his Revision of the Flora of the Green River Formation. The specimen I described as Celtis debequensis is identical with the type.

\section{MORACEAE}

\section{Ficus wyomingiana Lesquereux}

Ficus wyomingiana Lesquereux, U.S. Geol. Survey Terr. Rept., vol. 7 , p. 205, pl. 34, fig. 3, 1878.

Cinnamomum scheuchzeri Heer. Lesquereux, U.S. Geol. Survey Terr. Rept., vol. 8, p. 38, fig. 6, 1883.

Knowlton, U.S. Geol. Survey Prof. Paper 131, p. 140, 1923.

A comparison of the specimens of Lesquereux's Ficus wyomingiana and Cinnamomum scheuchzeri shows such striking similarities in every respect except size that I venture to assign them to a single species. The Cinnamomum scheuchzeri leaf is small and compares well with those figured originally by Heer ${ }^{22}$ from the Miocene lake deposits at Oeningen, Germany. That they are the same species, however, is perhaps unlikely.

Lesquereux gave the locality of this leaf as Florissant. The matrix, however, is the grayish-white laminated calcareous shale characteristic of and identical with that bearing many other fossil plants as cribed to the Green River formation in Uinta County. Wyo. Knowlton rejected this leaf from the Green River flora because, at the time of his writing, the type specimen was " not now known to be in existence." It has been found since then.

The chief difference between this species and Ficus mississippiensis (Lesquereux) Berry, formerly called Ficus pseudopopulus Lesquereux, which is also present in the Green River flora, seems to be the unusually high arching of the lateral primaries and the absence of prominent secondaries in the space between the primaries in the lower two-thirds of the leaf. This may, however, be only a variation from the normal $F$. mississippiensis leaf.

\section{PROTEACEAE}

\section{Lomatia coloradensis (Knowlton) Brown}

Phyllites coloradensis Knowlton, U.S. Geol, Survey Prof. Paper 131, p. 176 , pl. 38, fig. 3, 1923.

Pimelea spatulata Knowlton, idem, p. 163, pl. 37, fig. 6.

Melia coloradensis (Knowlton) Cockerell, U.S. Nat. Mus. Proc., vol. 66, art. 19, p. 3, 1925.

Lomatia obtusiuscula Cockerell, idem, p. 7, pl. 1, fig. 4.

Lomatia coloradensis (Knowlton) Brown, U.S. Geol. Survey Prof. Paper 154, p. 285, pl. 72, flgs. 3-6, 1929.

This is a variable species, as the synonymy suggests. Pimelea spatulata Knowlton is a single leaflet and agrees in every particular with the leaflets of Lomatia coloradensis. By oversight I omitted the third mem-

22 Heer, Oswald, Flora tertiaria Helvetiae, $\nabla 01,2$, p. 85, pl. 91. figs, 4-22; pl, $92 ; \mathrm{pl}, 93$, figs, 1, 5, 1856. 
ber of the synonymy from my 1929 publication. I confess inability to distinguish between this species and L. terminalis Lesquereux of the Florissant lake beds. Nevertheless they may be different and are tentatively so regarded.

\section{Banksia comptonifolia Brown, n.sp.}

Plate 9, figures 3-5

Thick linear leaves with coarsely toothed margins. Midrib strong. Secondaries numerous, curved upward into the teeth, with intermediaries running to the notches between the teeth. Base and petiole not present. The apex is bluntly acuminate. Choice of Banksia as a generic name for this species may leave much to be desired.

Occurrence: Three miles north of Rifle, Colo. (fig. 3); mouth of gulch on Roan Creek, 25 miles northwest of De Beque, Colo. (figs. 4, 5).

Types in United States National Museum.

\section{LAURACEAE}

\section{Oreodaphne coloradensis Brown, n.sp.}

Plate 10, figures 1,2

These are ovate-lanceolate leaves, 10 to 12 centimeters long and 3 to 4 centimeters wide, with petioles averaging 5 centimeters in length. The apex may be blunt or slenderly elongated to a rounded point. The base is wedge-shaped, and the margins are entire. The venation is characterized by two prominent lateral primaries, which arise from the midrib at a point 5 millimeters or more above the top of the petiole and arch upward to join the first secondaries near the margin midway between the base and apex of the leaf. The first secondaries depart from the midrib in the lower third of the leaf. Other secondaries few. Finer venation a lacework of horizontal or diagonal thin veins connecting the larger veins. The texture of the original leaf apparently was leathery. In general these fossils illustrate the characters of the leaves of the living lauraceous genera Cinnamomum and Oreodaphne.

These leaves may be compared chiefly with Cinnam.omum affine Lesquereux, ${ }^{23}$ from the Laramie at Golden, Colo., and with Oreodaphne obtusifolia Berry, ${ }^{24}$ from the Wilcox flora. The long petiole, entire margin, and coriaceous texture distinguish Oreodaphne coloradensis from other fossils described as Philadelphus, which have relatively short petioles, sometimes entire but usually with more or less toothed

\footnotetext{
${ }^{23}$ Lesquereux, Leo, The Tertiary flora: U.S. Geol. Survey Terr. Rept., vol. 7 , p. 219 , pl. 37 , figs. $1-5,7,1878$.

${ }^{24}$ Berry, E. W., The lower Eocene floras of southeastern North America: U.S. Geol. Survey Prof. Paper 91, p. 301, pl. 80, fig. 1; pl. 83 , figs. $2-5$; pl. 84 , figs. $1,2,1916$.
}

margins, especially toward the apices, and thin texture. The venation distinguishes this species from others in the Green River flora.

Occurrence: Parachute Creek, Colo. (fig. 1); 8 , miles west of Highmore, Colo. (fig. 2).

Type specimens in United States National Museum.

Oreodaphne lancifolia (Lesquereux) Brown, n.comb.

Sapindus lancifolius Lesquereux, C.S. Geol. Survey Terr. Rept., vol. 8, p. 182 , pl. 37, fig. 9 [not pl. 32, figs. 3-6, which are $S$. dentoni Lesquereux], 1883.

Oreodaphne fnowltoni Brown, U.S. Geol. Survey Prof. L aper 154 , p. 287, pl. 72, fig. 9, 1929.

Saxindus lancifolius was not included in the Green River flora by Knowlton. Lesquereux gave the locality of his specimen as Florissant, but an examination of the matrix shows that it is the characteristic grayish-white laminated calcareous shale of the Green River formation in Uinta County, Wyo., from which many other fossil plants have been described. I find that the venation and other characters of S. lancifolius are of the same type as in the specimen of Oreodaphne. knowitoni Brown, and I have accordingly made the new combination.

\section{BERBERIDACEAE}

\section{Odostemon eocenia Brown, n.sp.}

Plate 13, figure 6

This characteristic unsymmetrical, thi k leaflet exhibits the general ovate form, reticulate venation, and spinous margin of the living Odostemons, particularly $O$. nutkanus and $O$. aquifolium, which range throughout the Rocky Mountain region of the west. ern United States, occupying open meadows and sunlit spaces of hillsides in forests. This species differs from Odostemon florissantensis Cockerell ${ }^{25}$ and $O d c_{-}$ stemonsimplex (Newberry) Cockerell [Berberis simplex Newberry] ${ }^{26}$ in having more and shorter marginal spiness and a finer texture. Hollick ${ }^{27}$ has described Odostemon reynoldsii from the Green River shales near De Beque, Colo. After examination of the type specimen I am of the opinion that its venation does not justify its assignment to Odostemon but suggests that of Fraicinus flexifolia (Lesquereux) Brown, n.comb.

Occurrence: Near the top of fissile shale on Piceance Creek, 22 miles north of Rifle, Colo.

Type specimen in United States National Museum.

${ }^{25}$ Cockerell, T. D. A., The fossil flora of Florissant: Am. Mus, Nat. Hist. Eull., vol. 24, p. 91, 1908.

${ }^{26}$ Newberry, J. S., The later extinct floras of North America: U.S. Geol. Survey Mon. 35, p. 97 , pl. 56, fig. 2, 1898.

${ }^{27}$ Hollick, Arthur, New speeies of fossil plants from the Tertiary shales near De Beque, Colo.: Torrey Bot. Club Bull., vol. 56, p. 95 . pl. 2, ffg. 2, 1929. 


\section{ROSACEAE}

\section{Amygdalus gracilis Lesquereux}

Amygdalus gracilis Lesquereux, U.S. Geol, Survey Terr. Rept., vol. 8 , p. 199 , pl. 40 , fig. 13 [not figs. $12,14,15$ ] ; pl. 44 , fig. 6, 1883.

Knowlton, U.S. Geol. Survey Prof. Paper 131, p. 164, 1923. Quercus neriifolia Al. Braun. Lesquereux, op. cit., p. 155, pl. 31, fig. 12, 1883 .

Knowlton has discussed the status of this species. My own search through the collections of the United States National Museum has produced only one specimen (fig. 13) referred to by Knowlton. I have not seen the specimen (fig. 12) said to be in the Princeton University Museum; but reference to the two figures side by side on plate 40 convinces me that they are not the same species. The venation is strikingly different. Lesquereux gives Florissant as the locality for all these specimens, except figure 6 , which is said to come from Randolph [now Uinta] County, Wyo. The matrix of figure 13 is not a Florissant matrix but is identical with the laminated, light gray, fine-grained, compact, calcareous matrix of the Green River formation at the same locality in Uinta County, Wyo., where Hayden collected the specimen of figure 6 and many others described by Lesquereux.

Figures 14 and 15, which apparently represent fruits, are obscure, and, as pointed out by Knowlton, there is little or no reason for connecting them with the leaves or for assigning them to Amygdalus. Berry ${ }^{28}$ has found similar objects in the Wind River Basin of Wyoming and synonymizes figures 14 and 15 with a new species, Palmocarpon lesquerevocii Berry. This seems to be a very appropriate assignment, as palms are represented by fossil leaves in the deposits of that basin. Palms are also present in the Green River formation; but, as pointed out at the beginning, the specimens of figures 14 and 15 are not at hand for comparison as to matrix, and as no similar objects have been found in the Green River formation, it seems best to exclude Palmocarpon lesquereuwii Berry for the present from the floral list of that formation.

I have before me the specimen called Quercus neriifotia Al. Braun. This was described by Lesquereux, who gave the locality as Randolph (now Uinta) County, Wyo. Knowlton failed to include this species in his revision of the Green River flora, but its matrix is the same as that of Amygdalus gracilis, just discussed. This specimen is poorly preserved, especially in the marginal region, so that only some of the venational details and general outline can be made out. The illustration given by Lesquereux exaggerates the thickness of the petiole and lower part of the midrib. Taking these points into consideration, I am persuaded that the specimen agrees better with the

${ }^{28}$ Berry, E. W., A flora of Green River age in the Wind River Basin of Wyoming: U.S. Geol. Survey Prof. Paper 165, p. 67, 1930. characters of Amygdalus gracilis than with those of any Querous. The reference of both specimens to Amygdahus is, at best, doubtful.

\section{LEGUMINOSAE}

\section{Cassia hesperia Brown}

Plate 12 , figures $1-4$

Cassia hesperia Brown, U.S. Geol. Survey Prof. Paper 154, p. 287 , pl. 73 , fig. $6,1929$.

Banisteria bradleyi Brown, idem, p. 287, pl. 73, fig. 7 .

With the accumulation of a number of new specimens this species becomes a little more clearly differentiated. There is considerable variation among these specimens in respect to size, venation, and especially the shape of the apex, which may be blunt, slightly emarginate, or attenuated. The blunter, more ovate forms are somewhat like Leguminosites lesquereuxiana Knowlton described below. The formerly described species Banisteria bradleyi Brown also belongs here.

Occurrence: Near head of Ute trail, 30 miles northwest of De Beque, Colo. (figs. 1-3) ; west side of Piceance Creek, sec. 22, T. 1 N., R. 97 W., Colo. (fig. 4).

\section{Cercis tenuinervis (Lesquereux) Brown, n.comb.}

Ficus tenuinervis Lesquereux, U.S. Geol. Survey Terr. Rept., vol. 8 , p. 164, pl. 44, fig. 4,1878 .

The figure of this fragmentary leaf gives a false impression of the specimen's actual characters. Afte: cleaning up the type specimen I found that the leaf has a petiole 4 centimeters long extending to the right and downward from the base of the thick vein shown in the figure. The thin, broken lateral vein to the left of the thick vein is actually a fragment of the midrib Thus the thick vein becomes one of the laterals of what was apparently an entire-margined, cordate leaf. The secondary venation is very suggestive of that in the genus Cercis, which seems to me is a more fitting assignment than Ficus. This fossil came from Alkali Station, 30 miles north of Green River, Wyo.

\section{Leguminosites lesquereuxiana Knowlton}

Leguminosites cassioides Lesquereux, U.S. Geol, Survey Terr. Rept., vol. 7, p. 300, pl. 59, flgs. 1-4, 1878 .

Leguminosites lesquereuxiana Knowlton, U.S. Geol. Survey Bull. 152, p. 131, 1898.

Sophora coloradensis Knowlton, U.S. Geol. Survey Prof. Paper 131, p. 165, pl. 37, figs. 14-16; pl. 40, fig. 11, 1923.

Bumelia coloradensis Cockerell, U.S. Nat. Mus. Proc., vol, 66, art. 19, p. 4, pl. 1, fig. 5, 1925.

Dalbergia knowltoni Cockerell, idem, p. 5, pl. 1, fig. 3 .

Lesquereux's figures 1,2 , and 3 represent specimens collected above the fish bed at Green River, Wyo. Of these, figures 1 and 3 are very likely the same species and seem to be leguminous in character. Figure 2 is fragmentary and of doubtful affinity, Figure 4 
represents a specimen collected, according to Lesquereux, at Spring Canyon, near Fort Ellis, Mont. It appears to be different from figures 1 and 3 . These types, so far as I know, are not now in the collections of the United States National Museum. Figures 1 and 3 , however, represent so clearly the character of the fossils included in the above synonymy that I venture to place them all in the same species. That this species is a legume may well be questioned, because a number of other families include species with leaves or leaflets having characters similar to this species. Among these may be mentioned such genera as Mimusops, Bumetia, Eugenia, Reynosia, and Fagara. Whatever its true affinity may be, there is little difficulty in distinguishing this species from others in the Green River flora.

\section{Mimosites coloradensis Knowlton}

Mimosites coloradensis Knowlton, U.S. Geol. Survey Prof. Paper 131, p. 166, pl. 40, figs. 1-3, 1923.

Mimosites debequensis Brown, U.S. Geol. Survey Prof. Paper 154, p. 286, pl. 73, figs. 1-3, 1929.

Mimosites falcatus Brown, U.S. Geol. Survey Prof. Paper 154, p. 287 , pl. 73 , figs. $4,5,1929$.

The large number of specimens in the recent collections makes it possible to show that the last two species cited in the synonymy are merely larger or more falcate representatives of the previously described Mimosites coloradensis.

\section{Podogonium americanum Lesquereux}

\section{Plate 10 , figure 8}

Podogonium americanum Lesquereux, U.S. Geol. Survey Terr. Rept., vol. 7, p. 298, pl. 59, fig. 5; pl. 63, fig. 2 ; pl. 65, fig. 6, 1878.

Only figure 6 on plate 65 , cited above, represents a specimen reported by Lesquereux as coming from the Green River "group" near the mouth of White River [in Utah], Wyoming territory, and collected by Prof. William Denton. This specimen does not now appear to be in the collections of the United States National Museum. The specimen here figured seems to represent the species Lesquereux described. It has numerous camptodrome secondaries with a reticulated system of intermediaries. Both specimens possess characters which strongly suggest the living Amorpha fruticosa Linnaeus.

Podogonium americanum seems to be closely related to if not identical with the fossil species Gleditsiophyllum eocenicum Berry ${ }^{29}$ from the Wilcox group at Puryear, Tenn.

Occurrence: 12 miles northwest of Rio Blanco (Colo.) post office.

Figured specimen in United States National Museum.

${ }^{29}$ Berry, E. W., The lower Eocene floras of southeastern North America : U.S. Geol. Survey Prof. Paper 91, p. 238, pl. 46, figs. 1-7. 1916.

$58868-34-3$

\section{SIMARUBACEAE}

\section{Ailanthus lesquereuxi Cockerell}

Ailanthus longepetiolata Lesquereux, U.S. Geol. Survey Terr. Rept., vol. 8, p. 197 , pl. 40 , fig. 7 [not fig. 6 , which is Rhus longepetiolata (Lesquereux) Brown, n.comb.], 1883.

Ailanthus lesquerewxi Cockerell, Torreya, vol. 27, p. 95, 1927.

Lesquereux in 1883 described a leaf and a fruit under the common designation Ailanthus longepetiolata. Cockerell in 1927 segregated these objects, calling the fruit by a new name, $A$. lesquereuxi, but passing the leaf with the suggestion that it might be a species of Qvercus. The fruit is a characteristic Ailanthus fruit that is little if at all different from $A$. americana Cockerell, ${ }^{30}$ from the Florissant lake beds.

The outstanding characters of the leaf are the extremely long petiole, the numerous secondaries, and the toothed margin. Concerning the basilar tooth Lesquereux says, "protruding outside and apparently glandular." Reference to his figure 6 shows that the artist stressed this point. Now that the type specimen has been thoroughly cleaned and all the marginal teeth uncovered it is found that the figure is somewhat inaccurate. On the specimen the teeth are sharp-pointed, not blunt, as in the figure, and the basilar teeth are not glandular, nor do they protrude in any unusual manner. The base of the leaf is cuneate, not truncate, as in Ailanthus. It is obvious, therefore, as Cockerell in 1927 also pointed out, that this leaf does not possess the characters of a living Ailanthus leaflet. The numerous secondary veins with short intermediaries that do not reach as far as the teeth, together with the pointed, somewhat irregular, crenate-serrate teeth, and the long petiole, suggest to me the belief that this fossil is the terminal leaflet of a Rhus. It is therefore assigned to Rhus longepetiolata (Lesquereux) Brown, n.comb. No fossil showing the distinctive characters of an Ailanthus leaflet has yet been identified from the Green River formation. The presence of undoubted fruits, however, encourages the belief that some day the search for the leares will be rewarded with success.

\section{ANACARDIACEAE}

\section{Rhus variabilis (Newberry) Knowlton}

Plate 11, figures 1-4

Planera variabilis Newberry, U.S. Nat. Mus. Proc., vol. 5, p. 508, 1883; U.S. Geol. Survey Mon. 35, p. 83, pl. 66, fig. 7 [not figs. 5, 6, which are Planera inequilateralis (Lesquereux) Knowlton], 1898.

Rhus variabilis (Newberry) Knowlton, U.S. Geol. Survey Prof. Paper 131, p. 167, 1923.

Cockerell, U.S. Nat. Mus. Proc., vol. 66, art. 19, p. 4, 1925.

${ }^{30}$ Cockerell, T.D.A., Description of Tertiary plants: Am. Jour. Sci., 4th ser:, vol. 26, p. 539, fig. 3, 1908. 
Myrica alkulina Lesquereux. Brown, U.S. Geol. Survey Prof. Paper 154, p. 283, pl. 71, figs. 2, 3, 1929. ${ }^{31}$

Myrica undulata? Heer. Lesquereux, Leo, U.S. Geol. Survey Terr. Rept., vol. 7 , p. 131, pl. 17, figs. 6-8, 1878 .

Myrica ludwigii Schimper. Lesquereux, Leo, U.S. Geol. and Geog. Survey Terr. Bull., vol. 1, p. 385, 1875 [1876] ; Ann. Rept. for 1874, p. 311, 1876; U.S. Geol. Survey Terr. Rept., vol. 7, p. 133, pl. 65, fig. 9, 1878.

Myrica zachariensis Saporta. Lesquereux, Leo. U.S. Geol. Survey Terr. Rept., vol. 8, p. 146, pl. 45a, figs. 6-9 [not pl. 25, fig. 5], 1883.

Rhus nigricans (Lesquereux) Knowlton, U.S. Geol. Survey Prof. Paper 131, p. 168, 1923. Not Cupanites nigricans (Lesquereux) Berry, U.S. Geol. Survey Prof. Paper 92, p. 176 , pl. 34, fig. 7, 1924 .

Rhus myricoides Knowlton, U.S. Geol. Survey Yrof. Paper 131, p. 188, pl. 37, figs. 9-11, 1923.

Myrica sp. Knowlton, U.S. Geol. Survey Prof. Paper 131, p. 157, pl. 37, fig. 2, 1923.

Cockerell in 1925 reported the finding of the splendid specimen shown in plate 11 , figure 1 , and gave a description of it. Heretofore only separate leaflets or fragments had been described and figured, and in consequence, as the synonymy shows, there was some confusion in identification, which the present regrouping may or may not resolve. Rhus variabilis is now figured for the first time as a pinnately compound-leaved species.

It is possible that Rhus variabitis is an extremely variable species, or that several species not clearly distinguishable from one another are here grouped together. The assignment of this species to Rhus might well be questioned, although the resemblances to Rhus, except for the long petiolules, are most suggestive. I have some suspicions that it may be a Koelreuteria-perhaps the species that produced the characteristic fruit Koetrenteria viridifluminis (Hollick) Brown, n.comb., referred to below. It also resembles rather strikingly the variable-leaved Costa Rican species Dipterodendron costaricense Radlkofer.

This species appears to be closely related to if not identical with Rhus coriaroides Lesquereux ${ }^{32}$ from the Florissant lake beds. Some of its leaflets might also be compared favorably with Rhus hilliae Lesquereux ${ }^{33}$ and Rhus lesquereuxii Knowlton and Cockerell, ${ }^{34}$ likewise from the Florissant lake beds.

Occurrence: Near Osborn's cabin, NW1/4 sec. 6, T. 7 S., R. 100 W., 30 miles northwest of De Beque, Colo.

Figure 1 at University of Colorado; counterpart in United States National Museum. Figure 2 in Milwaukee Public Museum. Figures 3 and 4 in United States National Museum.

\footnotetext{
31. The synonymy from this point includes for the most part doubtful and poorly characterized species based upon fragmentary specimen that after careful comparisons seem to me to belong to the betterdescribed and better-figured Rhus variabilis (Newberry) Knowlton.

${ }^{32}$ Lesquereux, Leo, Cretaceous and Tertiary flora: U.S. Geol. Survey Terr. Rept., vol. 8 , p. 193, pl. 41, fig. $3,1883$.

${ }^{83}$ Idem, p. 194, pl. 41, figs. 12-15.

34 Knowlton, F. H., Mesozoic and Cenozoic plants of North America : U.S. Geol, Survey Bull. 696, p. 552, 1919 ,
}

Rhus longepetiolata (Lesquereux) Brown, n.comb.

Ailanthus longepetiolata Lesquereux, U.S. Geol. Survey Terr. Rept., vol. 8, p. 197 , pl. 40 , fig. 6 [not fig. 7 , which is A. lesquereuxi Cockerell], 1883.

Rhus myricoides Knowlton. Brown, U.S. Geol, Survey Prof. Paper 154, p. 287, pl. 73, fig. 9, 1929.

The specimen (pl. 73, fig. 9) referred by me in 1929 to Rhus myricoides Knowlton ${ }^{35} \mathrm{I}$ now find is distinguished from Rhus myricoides, herein referred to Rhus variabilis (Newberry) Knowlton, by having numerous small, closely spaced crenate-serrate teeth and a rounder, more asymmetric base. The teeth of $R$. variabilis are more widely spaced, with straighter sides, thus appearing angular instead of rounded, the total effect being one of dentateness rather than crenateness. The distinction in the secondary venation of the two species, while apparent to the eye, is difficult to convey in words, but it results chiefly from the differences in the nature and arrangement of the marginal teeth.

The status of the leaf Ailanthus longepetiolata Lesquereux is discussed in connection with $A$. lesquereuxi Cockerell. It is there pointed out that this leaf is neither an Ailanthus nor a Quercus, but very probably a terminal leaflet of Rhus longepetiolata.

Rhus longepetiolata resembles the living Rhus typhina Linnaeus very closely. It also suggests comparison with species of Sorbus. The latter, however, exhibit sharp-pointed teeth that are distributed to the very apices of the leaflets, whereas teeth are absent for some distance in the apical portion of $R$. longepetiolata leaflets, which in this respect are comparable to living species of Rhus.

Occurrence: The specimen figured by me in 1929 was collected by 0 . M. Ball between Carr and Brush Creeks, 30 miles northwest of De Beque, Colo. It is now at the Agricultural and Mechanical College of Texàs, College Station, Tex.

\section{Anacardites schinus Brown, n.sp.}

Plate 15, figure 19

This is a winged seed 1.6 centimeters long, the seed portion occupying about one-third the length of the entire object. Fine irregular striations are faintly visible on the wing. The general form and habit simlilates that of South American species of Schinopsis, hence the suggestion in the specific name.

Occurrence: Near Osborn's cabin, NW1/4 sec. 6, T. 7 S., R. 100 W., 30 miles northwest of De Beque, Colo.

Type in United States National Museum.

${ }^{35}$ Knowlton, F. H., Revision of the flora of the Green River formation: U.S. Geol. Survey Prof. Paper 131, p. 188, pl. 37, figs. 9-11. 1923. 


\section{CELASTRACEAE}

\section{Maytenus berryi Brown}

Plate 10, figure 7

Maytenus berryi Brown, U.S. Geol. Survey Prof. Paper 154, p. 289 , pl. 74 , fig. 3,1929 .

The specimen formerly figured did not show the venation of the leaf very clearly, hence the introduction of another figure. This specimen lacks the apex, is more finely serrate, and does not present the general falcate outline of the other, but venational details are identical in both. It was discovered, after the photograph and plate were made, that the petiole of this specimen is 1 centimeter long.

Occurrence: On Roan Creek, 25 miles northwest of De Beque, Colo.

Figured specimen in United States National Museum.

\section{ACERACEAE}

\section{Acer lesquereuxii Knowlton}

Acer indivisum Lesquereux, U.S. Geol. Survey Terr. Rept. vol. 8 , p. 180 , pl. 36 , fig. 6 [fig. 9 is A. mysticum Kirchner], 1883. (Homonym, Weber, 1852.)

Acer lesquereuxii Knowlton, U.S. Geol. Survey Bull. 152, p. 26, 1898; U.S. Geol. Survey Prof. Paper 131, p. 169, 1923.

Lesquereux's figures 6 and 9 represent, respectively, a leaf and a schizocarp of a maple. The seeds, which Knowlton reported as not to be found in the collections of the United States National Museum, were stored with the Florissant lake-bed specimens, where I found them. When I examined these types I found that the matrix was not the same for both specimens. The seeds are on a limeless thin brown-shale and volcanic-ash matrix, clearly of the Florissant lake-bed deposits. The leaf is on a grayish-white laminated calcareous shale, clearly a Green River formation matrix and identical with that in which many other Green River fossil plants are preserved. The leaf, as figured, does not show the long attenuated lobes which the specimen now shows after being cleaned by removal of a thin encrusting layer.

There are some superficial resemblances between this leaf and Liquidambar callarche Cockerell, which is not rare in the Green River flora. The sweeping, even curve of the nonserrate margin between the lobes, however, is in strong contrast to the rather sharp angle between the lobes and to the serrate margin of L. callarche leaves. This maple leaf can be duplicated almost exactly with leaves from the living Chinese maple, Acer pictum Thunberg, and its affinities may lie in that direction. Other leaves of $A$. pictum are strikingly like Liquidambar leaves except that the margin is entire, not serrate.
No maple seeds have thus far been found in the Green River formation, although one seed, Anacardites schinoloxus Brown, ${ }^{36}$ resembles a maple samara, but, as pointed out in the description of that species, there are features of that specimen which apparently eliminate it from the Aceraceae.

It does not seem proper to retain the same specific name for the leaf and seeds here discussed, as they clearly belong to different formations and localities and as in any case no connection between leaf and seeds can be demonstrated. I propose the retention of the name Acer lesquereuxii Knowlton for the leaf and the placing of the seeds under the designation Acer mysticum. Kirchner, ${ }^{37}$ from which they apparently cannot be distinguished.

\section{SAPINDACEAE}

\section{Sapindus dentoni Lesquereux}

Plate 13, figures 3,4

Sapindus dentoni Lesquereux, U.S. Geol. and Geog. Survey Terr. Bull., vol. 1, p. 388, 1875 [1876]; Ann. Rept. for 1874, p. 315, 1876; U.S. Geol. Survey Terr. Rept., vol. 7, p. 265, pl. 64, figs. 2-4, 1878.

Sapindus lancifolius Lesquereux, U.S. Geol. Survey Terr. Rept., vol. 8. p. 182, pl. 32, figs. 3-6 [not pl. 37, fig. 9], 1883. Salix sp. [S. media Heer] Knowlton, U.S. Geol. Survey Prof. Paper 131, p. 156, 1923.

Myrica torreyi Lesquereux. Brown, U.S. Geol. Survey Prof. Paper 154, p. 283, 1929.

The types of this species seen not now to be in the United States National Museum. However, a number of specimens from recent collections compare favorably with the figures given by Lesquereux for this species, and they are therefore assigned to Sapindus dentoni, called Sapindus lancifolius by Lesquereux. That of his plate 37 , figure 9 , differs from those of plate 32 , figures 3 to 6 , in having a more wedge-shaped base, stouter petiole, and fewer and more widely spaced secondary veins, which, so far as I can determine from the type specimen, do not unite near the margin to form an undulatory intramarginal vein pattern. This it seems is therefore a different species, not Sapindus but Oreodaphne, and is assigned to Oreodaphne lancifotia (Lesquereux) Brown.

The specimen called Salix sp. [Salix media Heer] by Knowlton and that called Myrica torreyi Lesquereux by me in a previous paper also belong here.

Occurrence: Between Carr and Brush Creeks, 30 miles northwest of: De Beque, Colo.

Figured specimens at Agricultural and Mechanical College of Texas, College Station, Tex.

${ }^{36}$ Brown, R. W., Additions to the flora of the Green River formation: U.S. Geol. Survey Prof. Paper 154, p. 288, pl. 73, fig. 8, 1929.

${ }^{37}$ Kirchner, W. C. G., Contributions to the fossil flora of Florissant, Colo. : St. Louis Acad. S.ci. Trans., vol. 8, p. 181, pl. 11, fig. 2, 1898. 
Koelreuteria viridifluminis (Hollick) Brown, n.comb.

Plate 10, figure 10

Staphylea viridifluminis Hollick, Torrey Bot. Club Bull., vol. 56 , p. 96 , pl. 2, fig. 3, 1929.

The specimen figured here is a single valve of a three-valved pod or capsule. In outline it is elliptical, 3.5 by 2 centimeters in dimensions. A prominent midrib divides the valve symmetrically. The midrib and heavy rim are connected by a number of irregular heavy veins, between which is a network of finer veins whose general direction is upward and outward from the midrib. The rounded apex carries a small, sharp point. The peduncle at the base, if originally present, is now missing. To the right of the midrib in the lower half of the specimen a portion of the placental wing showing the point of attachment for a seed was exposed by removal of a thin plate of surface material.

Except that Hollick's specimen, Staphylea viridifluminis, described in 1929, is slightly larger and is composed of three superposed valves - that is, a complete capsule-there is no further distinction from my specimen. I had the privilege of examining Hollick's specimen in 1931. After comparing it with mine, I concluded that they were identical species but did not belong to Staphylea. My reasons for excluding them from Staphylea are as follows: No Staphyleas when flattened by being embedded in sediments would leave impressions showing a strong midrib. On the contrary, the line marking the position of a midrib would be faint, and the apex of the imprint would show two separate points instead of one as in these fossils. Staphylea capsules are indehiscent except for a short distance near the apex and do not separate into three distinct valves. Staphyleas do not bear their seeds on a placental wing. Staphylea seeds are proportionally smaller than the seeds in these capsules. The heavier venation of Staphylea pods is more widely spaced than that shown in these fossils and shows a pattern of loops arching upward toward the apex. The venation of the fossils does not exhibit this longitudinal tendency. No leaves suggesting Staphylea have so far been discovered in the Green River shales unless they are those now called Juglans alkalina Lesquereux. Soon after seeing Hollick's specimen I enumerated to him the foregoing objections to its being Staphylea and suggested Koelreuteria instead. Hollick replied that he would reconsider the identification, but I did not hear from him further on the matter.

This fossil is very similar to if not identical with the objects described from the Florissant lake beds under a number of names summarized in the following synonymy:

Ophioglossum alleni Lesquereux, U.S. Geol. Survey Terr. Ann. Rept. for 1872, p. 371, 1873.
Salvinia alleni (Lesquereux) Lesquereux, U.S. Geol. Survey Terr. Rept., vol. 7, p. 65, pl. 5, fig. 11, 1878.

Tmesipteris alleni (Lesquereux) Hollick, Torrey Bot. Club Bull., vol. 21, pp. 253-257, pl. 205, 1894.

Carpolithes alleni (Lesquereux) Cockerell, Am. Jour. Sci., 4th ser., vol. 36, pp. 498-500, 1913.

Hollick, Torrey Bot. Club Bull., vol. 50, pp. 207-213, pls. 10-12, 1923.

Phyllites alleni (Lesquereux) Florin, Geol. Inst. Upsala Bull., vol. 16, pp. 249-260, pl. 11, 1919.

Brachyruscus alleni (Lesquereux) Cockerell, Torrey Bot. Club Bull., vol. 49, pp. 211-213, fig. 1, 1922.

Koelreuteria alleni (Lesquereux) Edwards, Annals and Mag. Nat. Hist., vol, 20, pp. 109-112, 1927.

In his 1923 paper Hollick figured a number of the Florissant fossils together with capsules of Koelreuteria and Staphylea but, except for pointing comparisons, refrained from suggesting a seventh generic name, leaving that responsibility to whoever should deem it necessary. W. N. Edwards in 1927 accepted the responsibility and assigned the fossils to Koelreuteria. He noted the fact that associated with these unique fruits in the Florissant lake beds are leaves highly suggestive of Koelreuteria. This is especially true of Rhus hilliae Lesquereux, ${ }^{38}$ one of the specimens of which in the United States National Museum collections is a bipinnate leaf after the manner of living Koelreuterias. Rhus is never bipinnate.

In the description of Staphylea viridifluminis, Hollick (1929) made no reference to his 1923 paper, nor did he compare his specimen with the similar Florissant objects he had previously studied. He suggested, however, that the Florissant leaves called Staphylea acuminata Lesquereux, ${ }^{39}$ although presumably somewhat later in age, may be related to the species which produced the fruit found in the Green River shales.

For the reasons already given I am of the opinion that both Hollick's specimen and mine represent not Staphylea but very probably Koetreuteria, the closest resemblance being to capsules of Koelreuteria bipinnata Franchet, from western China. Koelreuteria is a mesophytic genus of five species distributed in China and Japan in regions having a mild temperate climate. Comparison of the fossils with the capsules produced by other sapindaceous genera, such as Urvitlea and Cardiospermum, leaves much to be desired.

The Green River and Florissant specimens may represent the same species, but of this I am not absolutely certain. Therefore I am designating them tentatively as different.

Fossil leaves from the Green River shales that may represent the same tree which produced these fossil fruits are discussed under Rhus variabilis (Newberry)

\footnotetext{
${ }^{38}$ Lesquereux, Leo, The Cretaceous and Tertiary floras: U.S. Geol Survey Terr. Rept., vol. 8, p. 194, pl. 41, figs. 12-15, 1883.

${ }^{39}$ Lesquereux, Leo, The Tertiary flora: U.S. Geol. Survey Terr. Rept., vol. 7, p. 267, pl. 48, figs. $4,5,1878$.
} 
Knowlton and Comptonia insignis (Lesquereux) Cockerell.

Occurrence: On Brush Creek, 25 miles northwest of De Beque, Colo.

Figured specimen in United States National Museum.

Dodonaea viscosoides Berry

Plate 10 , figure 9

Dodoraea viscosoides Berry, U.S. Geol. Survey Prof. Paper 84, p. 142 , pl. 28 , figs. $4-8,1914$; U.S. Geol. Survey Prof. Paper 92 , p. 70 , pl. 12 , fig. 7 ; p. 176 , pl. 34, figs. 11-13; pl. 42, fig. 1, 1924 .

This leaf appears to be a slightly mutilated example of the species described by Berry from the middle and upper Eocene floras of the southeastern United States. There are some differences in venation between my specimen and Berry's, but they seem to be of a minor nature. All these specimens differ in venation from the living species Dodonaea viscosa Linnaeus but nevertheless resemble it closely.

Occurrence: Near head of Ute Trail, 30 miles northwest of De Beque, Colo.

Figured specimen in United States National Museum.

\section{ILICACEAE}

Ilex coloradensis Brown, n.sp.

Plate 10, figures 5,6

Thick lan eo ate leavés, 4 to 7 centimeters long and 1.5 to 2 centimeters wide. Apex elongated and acuminate; base broadly cuneate, equilateral. Petiole short. Margin sinuous, with few to numerous sharp, longpointed or serrate teeth. Midrib strong, straight. Secondaries few, 6 to 8 alternate pairs, diverging from the midrib at $45^{\circ}$ or more, curved upward into the teeth or camptodrome and sending an irregular loop to the secondary above, with veinlets to the teeth. Finer venation indistinguishable.

This form is referred to Ilex with reservations. It resemb'es in some respects certain fossil species of Myrica and Dillenites, and in particular it is like figure 7 of Ilex dissimilis Lesquereux ${ }^{40}$. but differs in being more ovate-lanceolate and in having a more acuminate apex. In $1929^{41}$ I assumed these leaves to be Ilex affinis Lesquereux, but now that I have had an opportunity to examine the types of that species and have found them to be small or deformed leaves of Quercus castaneopsis, it becomes necessary to set up this new species.

Occurrence: Between Carr and Brush Creeks, 30 miles northwest of De Beque, Colo.; collected by O. M. Ball.

Types at Agricultural and Mechanical College of Texas, College Station, Tex.

\footnotetext{
${ }^{40}$ Lesquereux, Leo, The Tertiary flora: U.S. Geol. Survey Terr. Rept., vol. 7, p. 77, pl. 50, figs. 7-9, 1878.

${ }_{41}$ Brown, R. W., Additions to the flora of the Green River formation : U.S. Geol. Survey Prof. Paper 154, p. 289, 1929.
}

\section{RHAMNACEAE}

\section{Zizyphus cinnamomoides Lesquereux}

Ceanothus cinnamomoides Lesquereux, U.S. Geol. and Geog. Survey Terr. Ann. Rept. for 1871, p. 289, 1872.

Zizyphus cinnamomoides Lesquereux, U.S. Geol. Survey Terr. Rept., vol. 7, p. 277, pl. 52, figs. 7, 8, 1878.

Ilex wyomingiana Lesquereux, idem, p. 270 , pl. 50, fig. 1.

Zizyphus longifolia Newberry, U.S. Nat. Mus. Proc., vol. 5, p. 513, 1882 [1883] ; U.S. Geol. Survey Mon. 35, p. 119, pl. 65, figs. 3-5, 1898.

This species left abundant remains in the Green River formation. It shows such variability and gradation of charaeters that, in my opinion, distinction from Zizyphus longifolia, described by Newberry and maintained by Knowlton, is impossible. Newberry's figure 5 appears to be merely an abnormal leaf, as suggested by its irregular outline. Ilex wyomingiana Lesquereux is a fragment of the upper portion of a leaf, but the venation indicates its reference to $Z$. cinnamomoides. Zizyphus claibornensis Berry ${ }^{42}$ from the Yegua ( $\uparrow$ Cockfield $^{43}$ ) formation, Columbia, La., is similar to if not identical with this species.

\section{TIITACEAE}

\section{Tilia seudderi (Cockerell) Brown, n.comb.}

Populus balsamoides latifolia Lesquereux, U.S. Geol. Survey Terr. Rept., vol, 8, p. 158, pl. 31, fig. 4, 1883.

Populus scuaderi Cockerell, Torrey Bot. Club Bull., vol. 33, p. 307, 1906: Colorado Univ. Studies, vol. 3, p. 172, 1976.

The large leaf described and figured by Lesquereux as Populnis balsamoides latifolia and renamed by Cockerell Populus scudderi is preserved on a gray calcareous matrix which is clearly a Green River, not a Florissant matrix, as originally cited. This leaf is a typical inequilateral linden leaf, but Lesquereux's figure, a drawing, does not accentuate that detail as it should. It may be compared with T. populifotia Lesquereux, ${ }^{44}$ from Florissant.

-4
20
20
ot

\section{MALVACEAE}

\section{Hibiscus roanensis Brown, n.sp.}

Plate 13, figure 1

The upper part of this leaf is missing. The portion remaining suggests that the leaf was of ovate or oblong shape, 10 centimeters or more long and 9 centimeters wide. The margin is sinuate with large, remotely placed teeth. The base is rounded. The length of petiole present is 3 centimeters. From

42 Berry, E. W., The middle and upper Eocene floras of southeastern North America: U.S. Geol. Survey Prof. Paper 92, p. 74, pl. 12, figs. $10,11,1924$.

${ }^{43} \mathrm{~A}$ dagger $(\dagger)$ preceding a geologic name indicates that the name has been abandoned or rejected for use in classification in publications of the U.S. Geological Survey.

44 Lesquereux. Leo, The Cretaceous and Tertiary floras: U.S. Geol, Survey Terr. Rept., vol. 8 , p. 179 , pl. 34, figs. 8, 9, 1883 . 
the top of the petiole two pairs of lateral veins, one pair stronger than the other, diverge toward the margin and send branches into the teeth. The next pair of strong secondaries departs from the midrib at some distance above the top of the petiole. The intermediate venation is irregular and obscure.

I have compared this leaf with numerous living species but have found no closer agreement than with the leaves of the Malvaceae, particularly the genus Hibiscus.

Occurrence: North side of Roan Creek, 30 miles northwest of De Beque, Colo.

Type in United States National Museum.

\section{BOMBACACEAE}

\section{Ochroma murata Brown, n.sp.}

\section{Plate 14}

This large entire-margined leaf is 25 centimeters wide at its greatest width, at a point about 12 centimeters above the base. The length of the preserved portion of the leaf is 18 centimeters, but it seems reasonable to infer that the missing apical portion, if restored, would add at least 5 centimeters to that length. The base is truncate to subcordate. The thick petiole, 8 millimeters in width, suffered distortion before fossilization and is now folded back upon the lamina of the leaf. The venation is palmate, with a heavy midrib flanked by 1 pair of strong and 2 pairs of weak lateral veins. The branchlets from these laterals, as well as the secondaries that depart from the midrib, unite near the margin to form an undulating intramarginal system. In life the leaf was apparently somewhat pubescent and of thin texture.

After comparing this leaf with living species of Platanus, Cucurbita, Sterculia, Hydrangea, Aratia, Quercus, Catalpa, Vitis, Populus, Dombeya, Ficus, Malva, Ochroma, and others, I conclude that it finds its closest counterparts in the genus Ochroma, one species of which, $O$. tagopus Swartz, from the tropics and subtropics of the Western Hemisphere, furnishes the corkwood or balsa of commerce. So far I have found no other evidence such as flowers or fruits to corroborate this identification, which must therefore be regarded as tentative rather than certain.

The venation, shape, and thick petiole of this leaf distinguish it from large fossil leaves that have been identified as Platanus, Aralia, Credneria, and Dombeyopsis.

Occurrence: North side of Roan Creek, 30 miles northwest of De Beque, Colo.

Type in United States National Museum. Named for Kiguma J. Murata, of the United States Geological Survey.
OLEACEAE

Fraxinus flexifolia (Lesquereux) Brown, n.comb.

Euonymus flexifolius Lesquereux, U.S. Geol. Survey Terr. Rept., vol. 8, p. 183, pl. 38, fig. 13, 1883.

Fraxinus petiolata Brown, U.S. Geol. Survey Prof. Paper 154, p. 290, pl. 75, figs. 1-4, 1929.

Odostemon reynoldsii Hollick, Torrey Bot. Club Bull., vol. 56, p. 95, pl. 2, fig. 2, 1929.

For the first time I have had an opportunity to examine Lesquereux's type of Euonymus flexifolius, and I find that, with all due respect to the delineator of the figure, the size and number of the marginal teeth are exaggerated and the number of secondary veins with intermediates is underestimated. In short, the general form and venation suggest that this specimen is a terminal leaflet of what I have previously described as Fraxinus petiolata. Although not to be considered proof, the fact that superposed on this specimen is an undoubted Fraxinus petiolata leaflet lends additional color to the hypothesis of identity as just stated.

Hollick described and figured a specimen called Odostemon reynoldsii. After examination of this specimen and comparison with the specimens of Fraxinus flexifotia in the United States National Museum, I am persuaded that it is a small leaflet of the latter species.

\section{Fraxinus wieser Brown, n.sp.}

Plate 12, figure 5

This is an odd-pinnately compound leaf. Leaflets 7 or more, thick, elliptic-lanceolate, entire, with margins slightly decurrent on the petiolule, which is about 1 centimeter long. Midribs of the leaflets strong. Secondaries, 10 or more pairs, camptodrome, at wide angles from the midrib.

This species can be compared with some of the many variable nonserrate forms of the living Fraxinus oregona Nuttall and Fraxinus velutina Torrey, of the western United States.

Occurrence: Alkali Station, Wyo.

Type in United States National Museum. Named for Miss Frances Wieser, of the United States Geological Survey.

\section{Syringa coloradea Brown, n.sp.}

Plate 10 , figure 4

This fine cordate leaf is 7.5 centimeters long and 5.5 centimeters wide. It has a strong midrib and rather thick petiole 1 centimeter long. The basal secondaries depart from the midrib at wide angles, but the higher secondaries leave at progressively narrower 
angles. Near the margin the secondaries fork or join the secondaries above. Finer venation obscure. Margin entire. Apex blunt. Base slightly cordate.

In outline this leaf resembles certain fossil forms described as Ficus, particularly some of the many forms of Ficus mississippiensis (Lesquereux) Berry. The venation, however, strikingly suggests that of Syringa, the lilac, rather than Ficus. Syringa is further suggested by such flowers as are shown in plate 8 , figure 5, and such fruits as are shown in plate 8, figure 13.

There are some 30 living species of Syringa native to eastern Asia and Japan.

Occurrence: Uinta County, Wyo.

Type in United States National Museum.

\section{APOCYNACEAE}

Apocynophyllum roanense Brown, n.sp.

Plate 11, figure 5

Salix sp. Knowlton, U.S. Geol. Survey Prof. Paper 131, p. 156, pl. 37, fig. 4, 1923.

These are coriaceous leaves, lanceolate, with entire margin, blunt apex, and cuneate base. Length of petiole unknown, but in Knowlton's specimen I uncovered slightly more than 1 centimeter. The venation is chararteristically irregular, the secondaries diverging from the midrib at angles of $45^{\circ}$ at the base but at nearly $90^{\circ}$ toward the apex of the leaf. They curve upward and fork near the margin. Between the secondaries are numerous finer irregular veinlets and an ultimate areolation somewhat like that of Quercus. This species differs from A pocynophyllum wilcoxense Berry in being less linear and more ovate-lanceolate.

Occurience: On south point of divide between middle and west forks of Parachute Creek, 10 miles northwest of Grand Valley, Colo.

Type in United States National Museum.

\section{Apocynospermum coloradensis Brown}

Plate 10 , figure 3

Apocynospermum coloradensis Brown, U.S. Geol. Survey Prof. Paper 154, p. 291, 1929.

The figured specimen will illustrate the type described but not figured in the paper cited above.

Occurrence: High bluff at south point of divide between middle and west forks of Parachute Creek, 10 miles northwest of Grand Valley, Colo.

Type in United States National Museum.

\section{CAPRIFOLIA.CEAE}

Viburnum asperum Newberry

Viburnum asperum Newberry. [Lesquereux], Illustrations of Cretaceous and Tertiary plants, pl. 16, fig. 8, U.S. Geol. and Geog. Survey Terr., 1878.
Newberry, U.S. Geol. Survey Mon. 35, p. 129, pl. 33, fig. 9, 1898.

Ward, U.S. Geol. Survey Bull. 37, p. 113, pl. 55, figs. 4-9, 1887.

Alnus kefersteinii (Goeppert) Unger. Lesquereux, U.S. Geol. Survey Terr. Rept., vol. 7, p. 140, pl. 64, fig. 11, 1878.

The specimen that Lesquereux called Alnus kefersteinii (pl. 64, fig. 11, 1878) is fragmentary, showing only the upper two-thirds of a leaf. The venation is fairly clear, and the margin, although somewhat ragged, exhibits a few distinct teeth. The types of Alnus kefersteinii (Goeppert) Unger were originally called Alnites kefersteinii Goeppert ${ }^{45}$ and represent inflorescences only. Later Unger ${ }^{46}$ changed the generic name to Alnus and figured 4 specimens, 3 of which are inflorescences and 1 (fig. 4) is a fragmentary leaf. From this beginning there has grown a large body of descriptions and figures purporting to represent Alnus kefersteinii. In Lesquereux's specimen I am unable to recognize much resemblance to the originally figured leaves of that species. The specimen, however, compares favorably with Viburnum asperum Newberry of the Fort Union formation. This species is closely related to if not identical with a number of other Viburnums from the Fort Union formation.

Lesquereux's Alnus leefersteinii (1878) was omitted from the Green River flora by Knowlton, although he included Sapindus obtusifolius Lesquereux, which occurs at the same locality and in the same matrix. The history of the specimen may explain the confusion in regard to it. Lesquereux, ${ }^{47}$ giving the locality of Sapindus obtusifotius, says: "Eight miles southeast of Green River station, Wyoming, in connection with thin beds of coal referable to the Washakie or Carbon group. A bed of shale is at this locality filled with leaflets of this species mixed with fragments of leaves and branches of Musophyllum. I could find there no other species. Mr. Wm. Cleburn, who visited later the same locality, has, among numerous specimens of these 2 species, 1 fragment of Carpinus grandis." Lesquereux, however, does not list Carpinus grandis with the Green River flora but lists and figures four specimens from the Florissant lake beds. Giving the locality for Alnus teefersteinii lie says (idem, p. 141) : "The fragment represented on pl. 64, near Florissant, South Park, Colo. (Dr. F. V. Hayden). Nine miles southeast of Green River, Wyo. (Wm. Cleburn)."

The matrix of this specimen, however, is a lightbuff, fine-grained clayey sandstone, which is entirely

45 Goeppert, H. R., De floribus in statu fossili : Acad. Caes. Leop. ('ar. Nova Acta, vol. 18, p. 564, pl. 41, figs. 1-7, 1838.

46 Unger, Franz, Chloris pratogaea: Beiträge zur Flora der Vorwelt, p. 115 , pl. 33 , figs. $1-4,1847$.

17. Lesquereux, Leo, The Tertiary flora: U.S. Geol. Survey Terp Rept., vol. 7, p. 266, 187 , 
unlike the reddish-brown, thinly laminated Florissant lake deposits composed largely of tuffaceous materials. The matrix is clearly the same as that from which the Sapindus obtusifolius was derived, and the inference logically follows that an error was made in ascribing this specimen to Florissant.

I have searched the collections of fossil plants in the United States National Museum and have found no Carpinus grandis labeled by Lesquereux as coming from the Green River formation. It is possible, therefore, that Lesquereux changed his identification without changing the record at one point from Carpinus grandis to Alnus kefersteini. Reference of the specimen to either of these genera does not in my opinion seem justified; but the recent work of Wodehouse on the pollens of the Green River shales indicates the presence of Alnus, Carpinus, and probably Viburnum in the Green River flora. The presence of Viburnum is further suggested by a seed called Carpites viburni Lesquereux. ${ }^{48}$

\section{CUCURBITACEA}

\section{Cucurbita glandulosa Brown}

Plate 13, figure 2

Cucurbita glandulosa Brown, U.S. Geol. Survey Prof. Paper 154, p. 291, pl. 75, fig. 6, 1929.

The specimen described and figured in 1929 was very fragmentary, including only 1 centimeter of petiole and the basal portion of the leaf. The present specimen is larger, showing the lobed nature of the leaf, but it lacks the apical portion. The minute punctation noted on the first specimen is characteristically present here also, so that taking all the evidence into consideration, I am of the opinion that the two specimens represent the same species. That they are cucurbitaceous in relationship may well be questioned, but I should feel equally doubtful in referring them to Platanus, Sterculia, Malva, Aralia, Quercus, or others.

Occurrence: North side of Roan Creek, 30 miles northwest of De Beque, Colo.

Figured specimen in United States National Museum.

\section{FLANTS OF UNCERTAIN AFFINITY}

\section{Phyllites ericoides Brown, n.sp.}

\section{Plate 13, figure 7}

This thick obovate to spatulate leaf has a strong straight midrib, but the remaining venation, except for a pair of alternate camptodrome secondaries rising from the midrib halfway between the base and apex, is obscure. On the basis of one leaf of this sort

${ }^{48}$ Lesquereux, Leo, The Tertiary flora: U.S. Geol. Survey Terr. Rept., vol. 7 , p. 305 , pl. 60 , figs. $26,26 a, 1878$.
I hesitate to suggest any generic affinities. The general outline and texture are not unlike some Ericaceae. Comparison might be made with Andromeda delicatula Lesquereux, ${ }^{49}$ from the Green River formation of Uinta County, Wyo. Examination of these specimens, however, reveals an entirely different venation.

Occurrence: Near head of Ute Trail, 30 miles northwest of De Beque, Colo.

Type in United States National Museum.

Phyllites furcivena Brown, n.sp.

Plate 13, figure 5

This elongate, narrow, coarse-toothed leaf with delicate bifurcating venation, has some suggestion of being a fern, somewhat like Aneimia delicatula Brown, ${ }^{50}$ but this resemblance may be only superficial. Future collections must be depended upon to furnish evidence for better determination of this form.

Occurrence: On Roan Creek, 25 miles northwest of De Beque, Colo.

Type in United States National Museum.

\section{Phyllites glandiferus Brown, n.sp.}

Plate 11, figure 7

This odd-pinnately compound leaf is somewhat peculiar in having long-petioled instead of sessile lower leaflets. The lower leaflet preserved is also peculiar in having a pair of minute glands at the base of the blade. Neither the terminal nor the sessile leaflets show this detail. It should be noted that the lower leaflet is unattached, and it may not belong to the main leaf; but in venation, texture, and general form it is so like the other leaflets that I consider it a part of the unit. The venation of the leaflets is indistinct but is leguminous in character. I offer no generic reference for this species; but there is some resemblance to the leaflets of Mimosites coloradensis Knowlton. ${ }^{51}$

Occurrence: On Piceance Creek, 20 miles west of Meeker, Colo.

Type in United States National Museum.

\section{Phyllites ouratea Brown, n.sp.}

Plate 11, figure 6

This fragment has a strikingly irregular secondary venation which is matched by a ragged margin showing coarse, hooked teeth of different sizes. In spots

${ }^{49}$ Lesquereux, Leo, The Cretaceous and Tertiary floras: U.S. Geol. Survey Terr. Rept., vol. 8, p. 175, pl. 34, figs. $10,11,1883$.

${ }^{5} 0$ Brown, R. W., Additions to the flora of the Green River formation: U.S. Geol. Survey Prof. Paper 154, p. 281, pl. 10, figs. 1, 2, 1929.

5 Knowlton, F. H., Revision of the flora of the Green River formation: U.S. Geol. Survey Prof. Paper 131, p. 166, pl. 40, figs. 1-3, 1923. 
the margin has been eroded. Comparison could be made with Ouratea eocenica Berry. ${ }^{52}$ This leaf may represent some herbaceous plant.

Occurrence: 3 miles northwest of De Beque, Colo.

Type in United States National Museum.

\section{Antholithes, species of}

Plate 15, figures 1-7

The series of flowers and flowerlike objects here figured are, it seems to me, of insufficient character to warrant more than guesses as to their identities.

Figure 1 is perhaps a cruciferous or onograceous flower. It is partly reconstructed.

Figure 2 is either a pedicellate calyx or corolla with the filaments of many stamens protruding.

Figure 3 has the appearance of two petals or sepals and a malvaceous cluster of numerous stamens.

Figure 4 is a flower with a superior ovary surrounded by the five-toothed calyx.

Figure 5 is a tubular receptacle, surmounted by a four-parted calyx.

Figure 6 is either a four-parted calyx or corolla with 8 to 10 stamens.

Figure 7 may be a large flower or a badly distorted leaf of a Netumbo.

Occurrence: Above Seller's ranch, north side of Roan Creek, 30 miles northwest of De Beque, Colo. (figs 2, 3, 5, 6) ; north side of Greenwood Creek, sec. 16, T. 2 N., R. 98 W., Colorado (fig. 4) ; Fossil, Wyo. (figs. 1, 7).

Types in United States National Museum.

Carpolithus alabaccus Brown, n.sp.

Plate 15, figure 11

This object appears to be a small winged seed, but it may be a berrylike fruit enveloped in a membranaceous sac. I do not offer any guess as to its generic affinity.

Occurrence: West side of Piceance Creek, sec. 22, T. 1 N., R. 97 W., Colorado.

Type in United States National Museum.

\section{Carpolithus cassioides Brown}

Plate 15, figure 8

Carpolithus cassioides Brown, U.S. Geol. Survey Prof. Paper 154, p. 291, pl. 76, fig. 1, 1929.

These specimens seem to be undoubted leguminous fruits and help to confirm the tentative identifications of such leaves as Mimosites, Cassia, Leguminosites, etc.

52 Berry, E. W., Revision of the lower Eocene Wilcox flora: U.S. Geol. Survey Prof. Paper 156, p. 112, pl. 45, fig. 3, 1930.
Occurrence: Near head of Ute Trail, 30 miles northwest of De Beque, Colo.

Figured specimen in United States National Museum.

$$
\begin{aligned}
& \text { Carpolithus filiferus Brown, n.sp. } \\
& \text { Plate 15, figures 17, } 18
\end{aligned}
$$

These specimens, ovoid to spherical, 2 to 4 centimeters in diameter, appear to be fruits covered with long silky hairs. On one side or end is a round scar which may have been a point of attachment. These objects may be palm fruits. The long filaments may be algae, and they may represent the same object described by Cockerell ${ }^{53}$ as a feather, Diatryma filifero. Cockerell.

Occurrence: Above Seller's ranch, north side of Roan Creek, 30 miles northwest of De Beque, Colo. (fig. 17); between Carr and Brush Creeks, 30 miles northwest of De Beque, Colo. (fig. 18).

Type, figure 17, in United States National Museum; figure 18, at Agricultural and Mechanical College of Texas, College Station, Tex.

\section{Carpolithus insectoides Brown, n.sp.}

Plate 15 , figure 9

This object appears to be a winged seed. The seed portion is heavy and pointed but grades insensibly. into the fine-veined ovate wing. Suggestions as to generic affinity are not offered at this time.

Occurrence: On Roan Creek, 25 miles northwest of De Beque, Colo.

Type in United States National Museum.

\section{Carpolithus paliuroides Brown, n.sp.}

Plate 15, figure 12

This fruit is 1 centimeter in diameter and is attached to a pedicel, of which the portion preserved is 1 centimeter in length. The center of the specimen is occupied by what was evidently the bulky portion of the fruit. Outside this heavier center is a thinner portion, which may represent something like the wing characteristic of Paliums fruits. If this thinner outer portion represents only the wrinkled skin of a globular stone fruit, the specimen may be compared with the fruits of the genus Zizyphus of the Rhamnaceae. This is a more likely reference, because leaves identified as Zizyphus cinnamomoides Lesquereux are locally very common.

Occurrence: Above Seller's ranch, north side of Roan Creek, 30 miles northwest of De Beque, Colo.

Type in United States National Museum.

${ }^{53}$ Cockerell, T. D. A., Plant and insect fossils from the Green River Eocene of Colorado: U.S. Nat. Mus. Proc., vol. 66, art. 19, pl. 1, fig. 7, 1925. 


\section{Carpolithus prunoides Brown, n.name}

Carpolithus ellipticus Brown, U.S. Geol. Survey Prof. Paper 154 , p. 291, pl. 76 , fig. 2, 1929 . Not C. ellipticus Sternberg, Flora der Vorwelt, vol. 1, p. 40, pl. 7, fig. 1, 1825.

By oversight this species received a name that was preempted, as stated in the citation.

\section{Carpolithus vitaceus Brown, n.sp.}

Plate 15, figure 10

This seed has every appearance of belonging to some member of the grape family, Vitaceae. This bit of evidence strengthens the position of such previously described objects from the Green River forma- tion as Parthenocissus tertiaria (Lesquereux) Knowlton, Caulinites prehensus Brown, and Antholithes vitaciflora Brown.

Occurrence: Near head of Kimball Creek, 30 miles northwest of De Beque, Colo.

Type in United States National Museum.

Carpolithus, species of

Plate 15, figures $13-16$

These fruitlike objects are figured as a matter of record, in the hope that the future may furnish evidence for their identification.

Occurrence: Near head of Ute Trail, 30 miles northwest of De Beque, Colo.

Figured specimens in United States National Museum. 


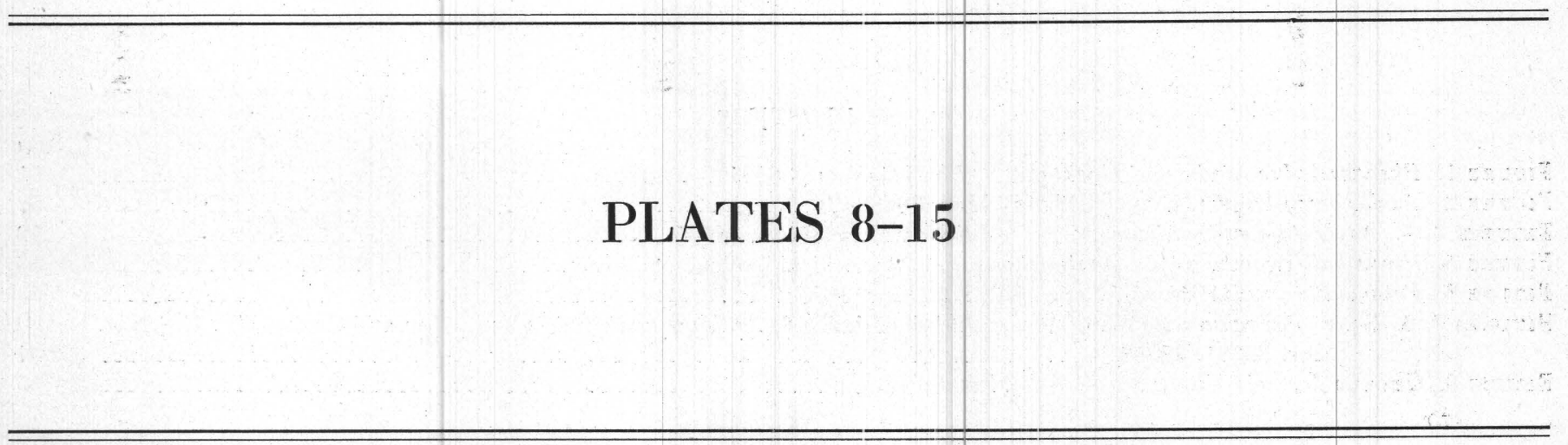




\section{PLATE 8}

FIGURe 1. Phenacocladus hendersoni Cockerell. U.S.Nat.Mus. 38581

Figure 2. Azolla berry Brown, n.sp. U.S.Nat.Mus. 38583

FIgURes 3, 4. Asplenium eoligniticum Berry. U.S.Nat.Mus. 38584, 38585

Figure 5. Pinus ball Brown, n.sp. Agricultural and Mechanical College of Texas

Figure 6. Potamogeton rubus Brown, n.sp. U.S.Nat.Mus. 38586

Figures 7, 8. Salix longiacuminata Knowlton. On left of figure 8, Aralia wyomingensis Knowlton and Cockerell. U.S.Nat. Mus. 38587,38588

FiguRe 9. Quercus drymeia Unger. U.S.Nat.Mus. 38589 
U.S. GEOLOGICAL SURVEY

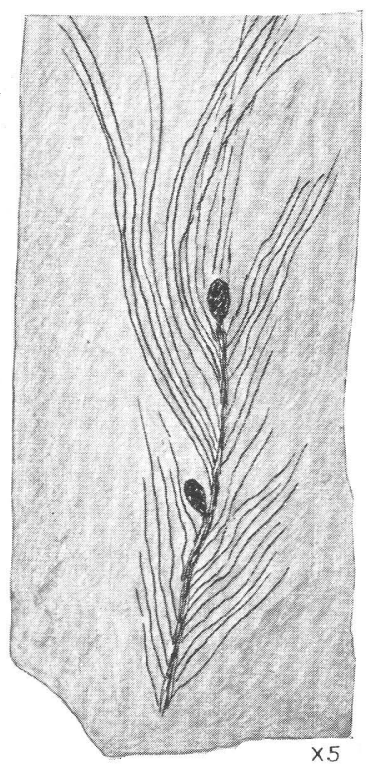

1

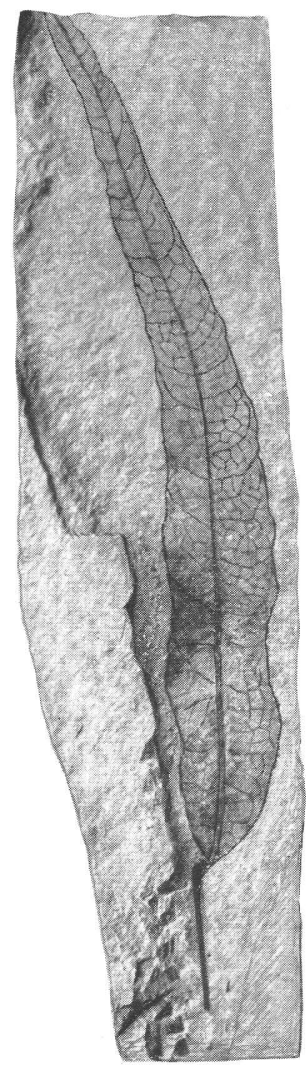

7

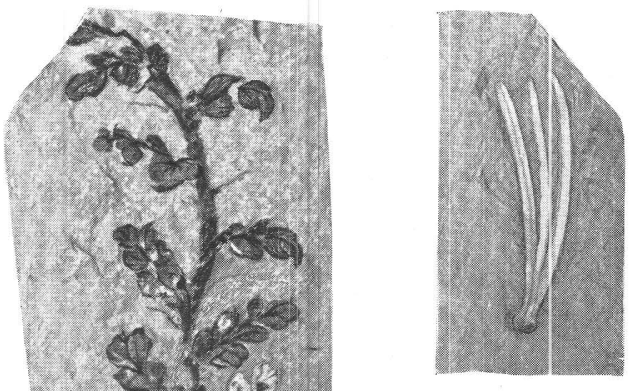

5

PROFESSIONAL PAPER 185 PLATE 8

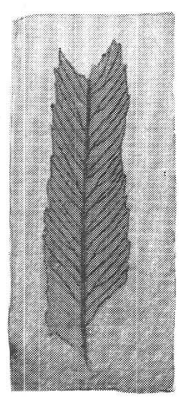

3
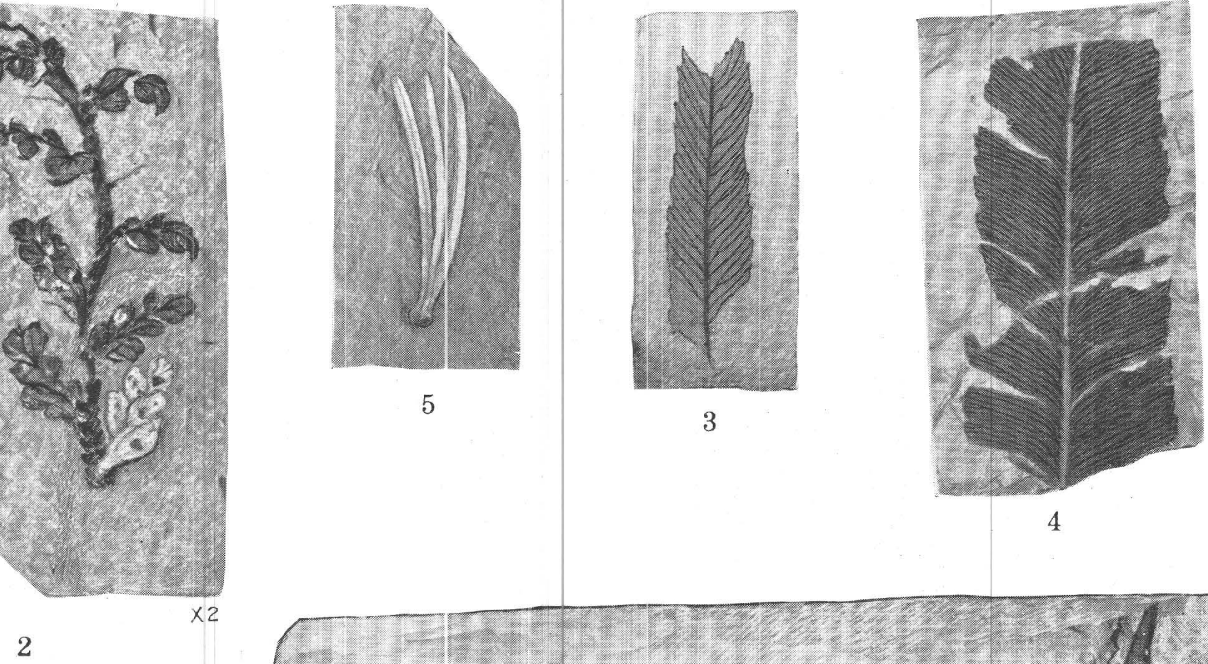

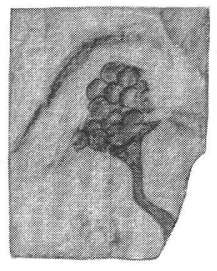

6

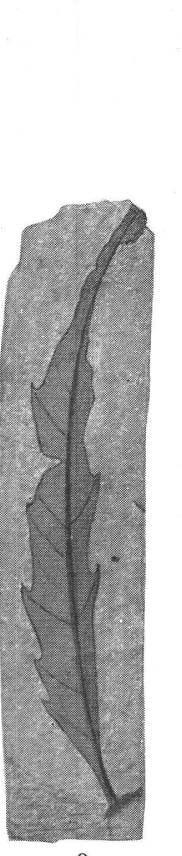

9
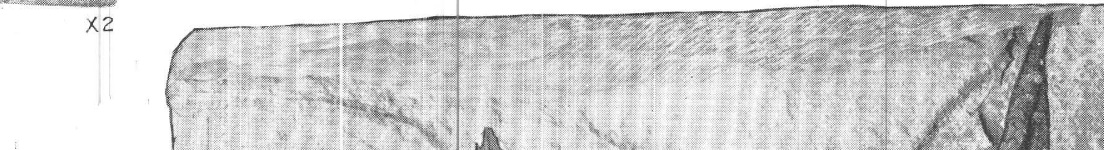

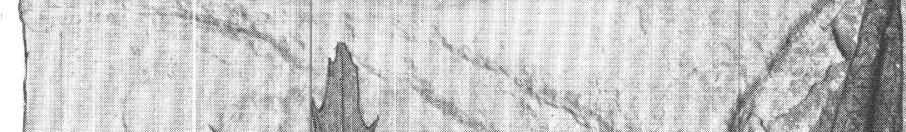

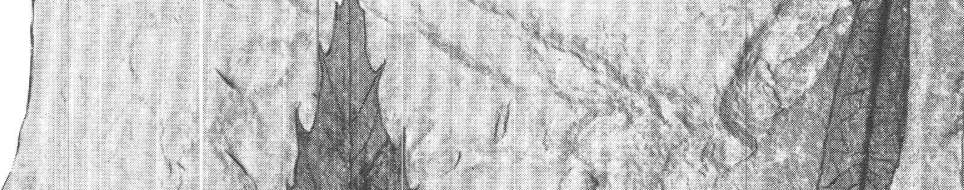

FOSSIL PLANTS FROM THE GREEN RIVER FORMATIONON. 
U.S. GEOLOGICAL SURVEY

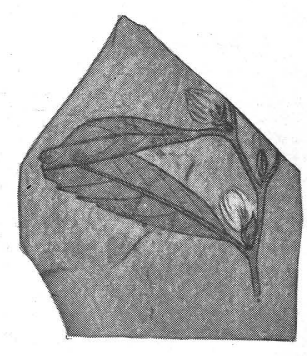

1

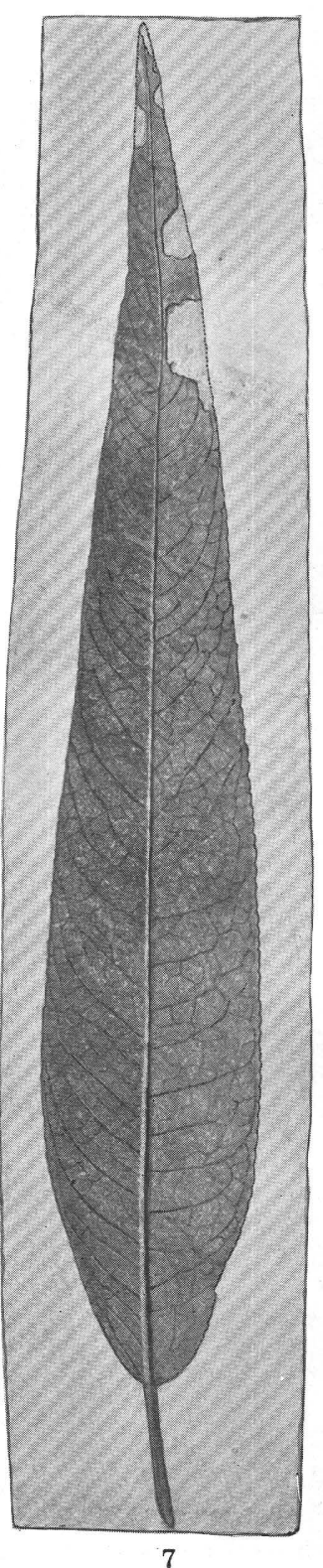

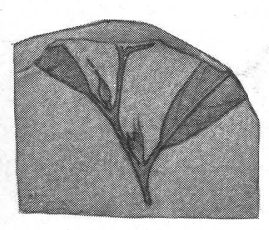

2

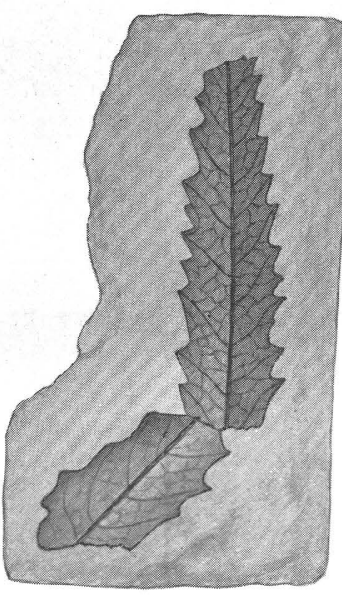

3

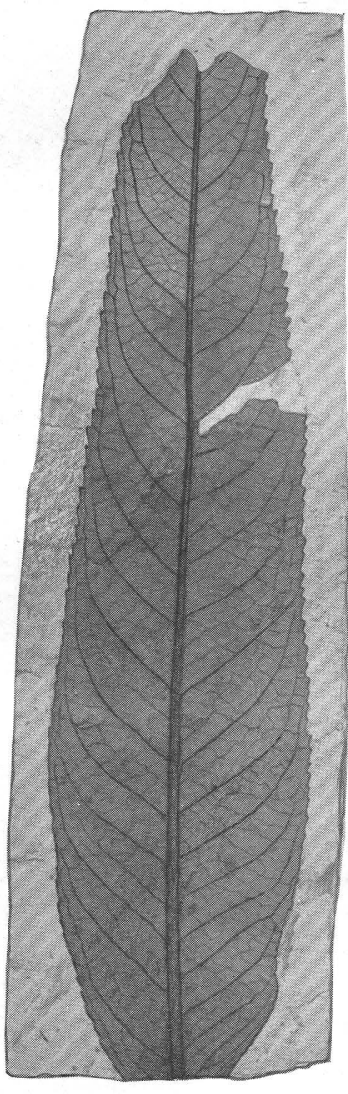

8
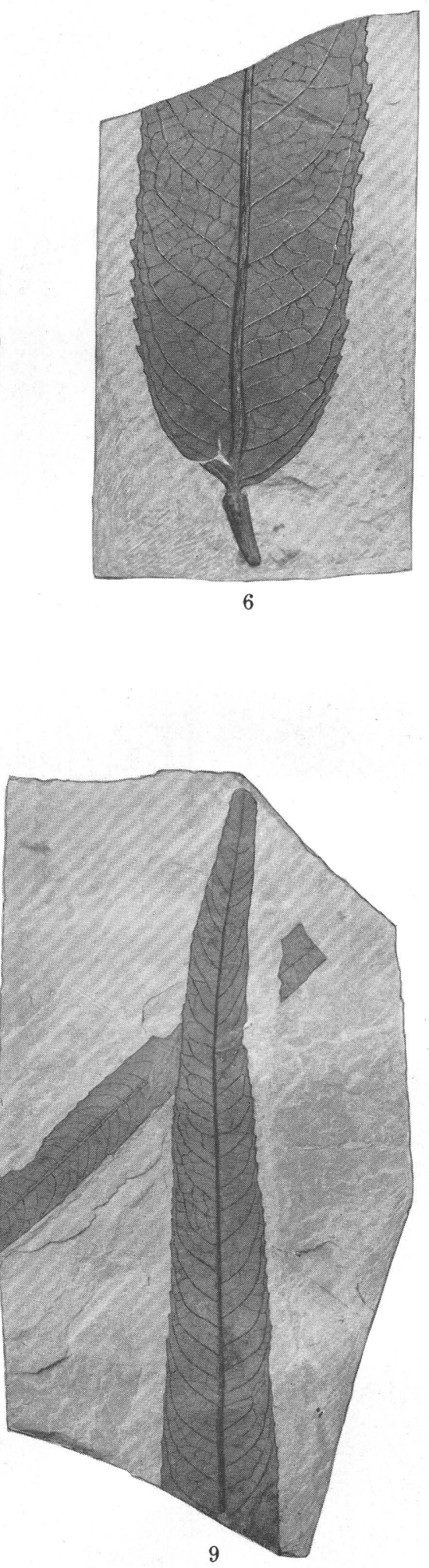

9

PROFESSIONAL PAPER 185 PLATE 9

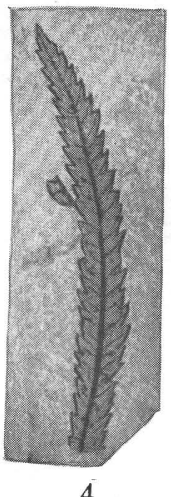

4

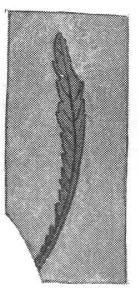

5

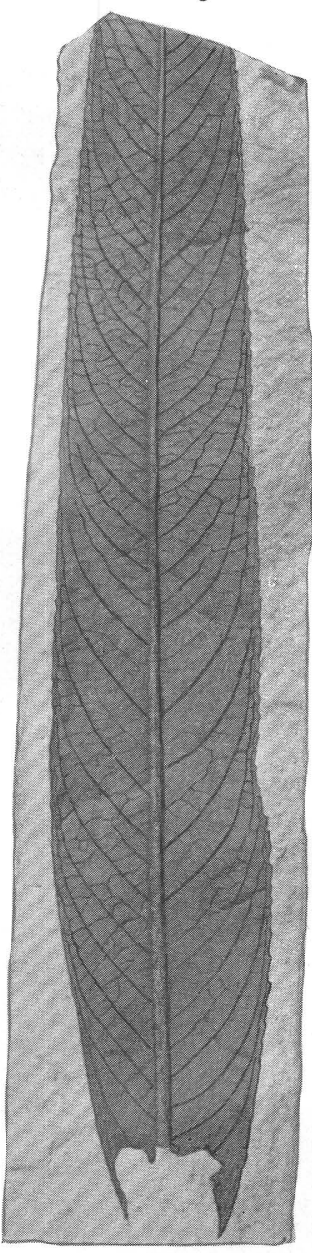

10

FOSSIL PLANTS FROM THE GREEN RIVER FORMATION. 


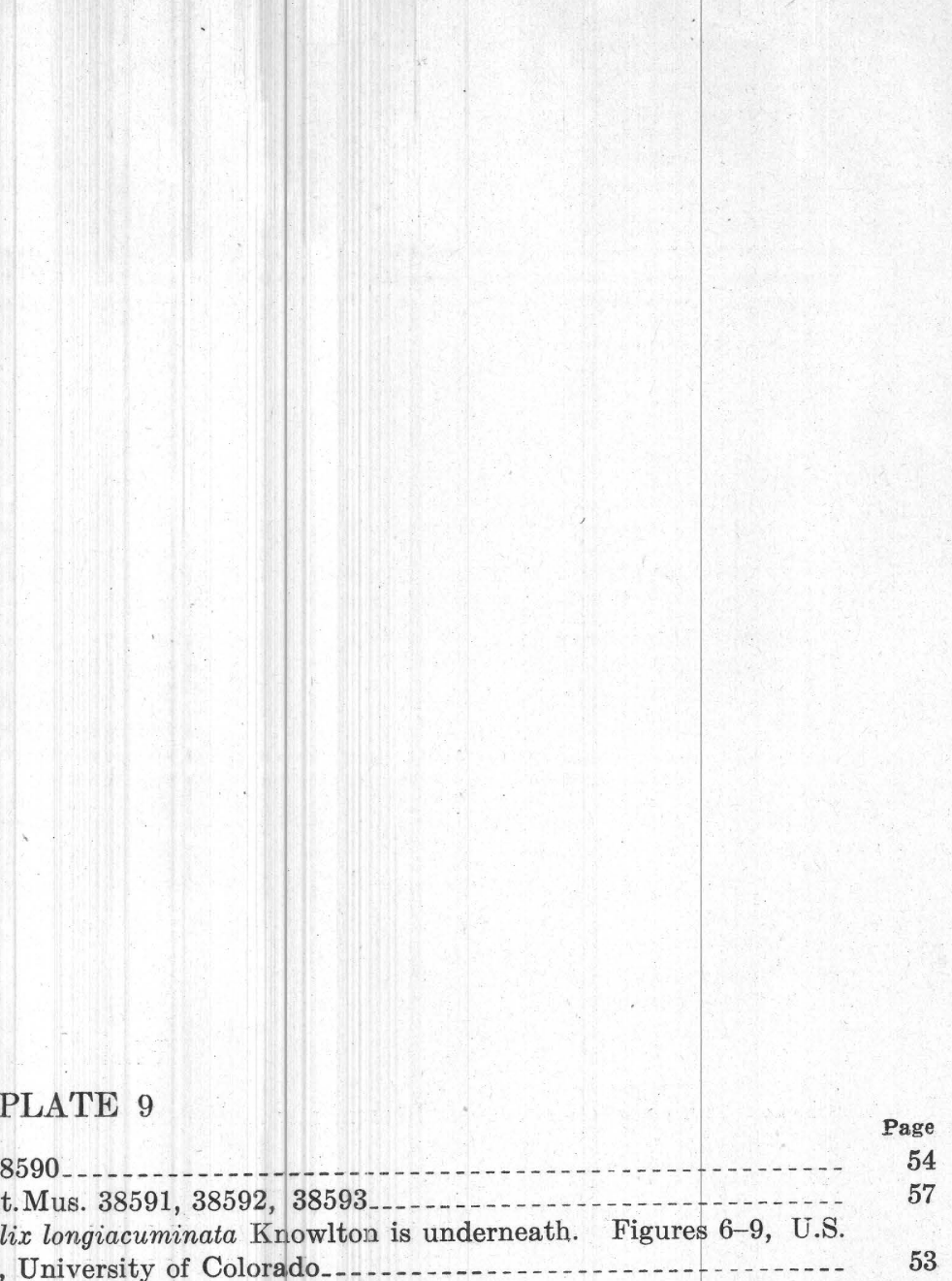

FigURES 1, 2. Myrica minuta Knowlton. U.S.Nat.M. U.S.Nat.Mus. 38591, 38592, 38593

FIGURES 6-10. Salix cockerell Brown, n.sp. In figure 9 Salix longiacuminata Knowlton is underneath. Figures 6-9, U.S. Nat.Mus. 38594, 38595, 38596; figure 10, University of Colorado_... 
PLATE 10

Figdres 1, 2. Oreodaphne coloradensis Brown, n.sp. U.S.Nat:Mus 38597,38598 57

pocynospermum coloradensis Brown. U.S.Nat.Mus. 38600

FIGURE 4. Syringa coloradea Brown, n.sp. U.S.Nat.Mus. 9694

Figures 5, 6. Ilex coloradensis Brown, n.sp. Agricultural and Mechanical College of Texas.

FIGURE 7. Maytenus berryi Brown. U.S.Nat.Mus. 38601

Figure 8. Podogonium americanum Lesquereux. U.S.Nat.Mus. $38602 \ldots$

Figure 9. Dodonaea viscosoides Berry. U.S.Nat.Mus. 38603

FIGURE 10. Koelreuteria viridifluminis (Hollick) Brown, n.comb. U.S.Nat.Mus. 38604 
U.S. GEOLOGICAL SURVEY

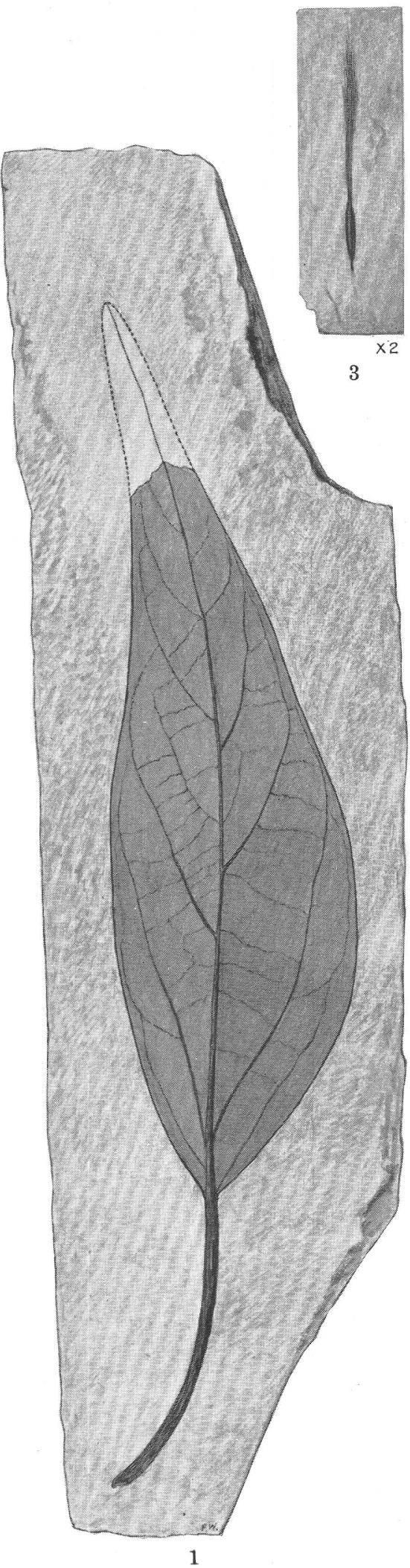

PROFESSIONAL PAPER 185 PLATE 10

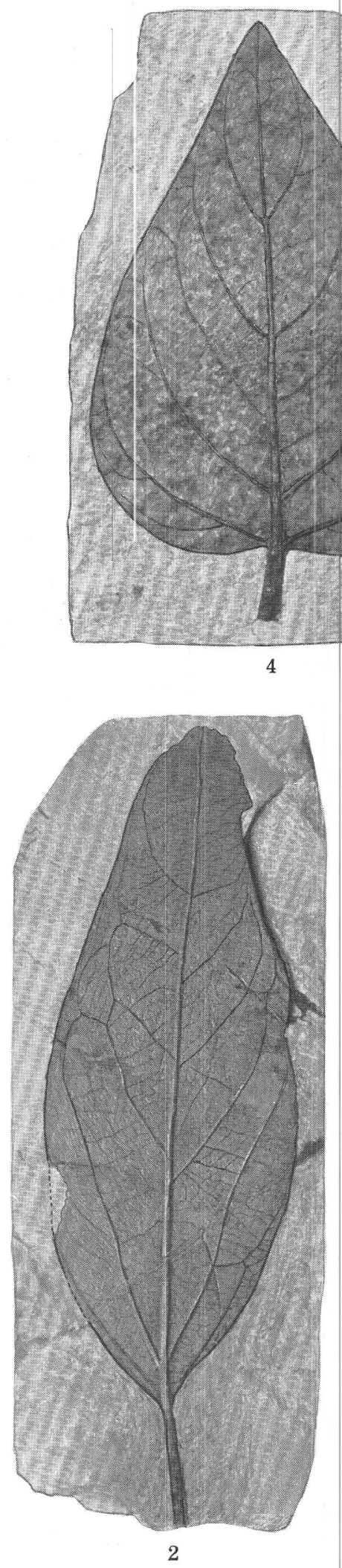

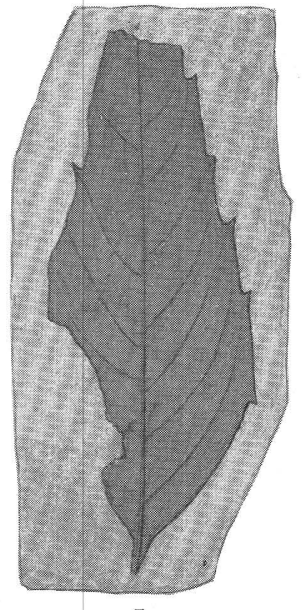

5
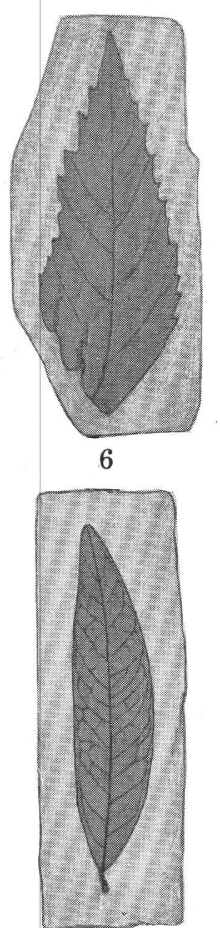

8

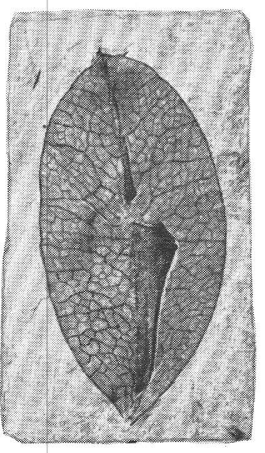

10

FOSSIL PLANTS FROM THE GREEN RIVER FORMATION. 

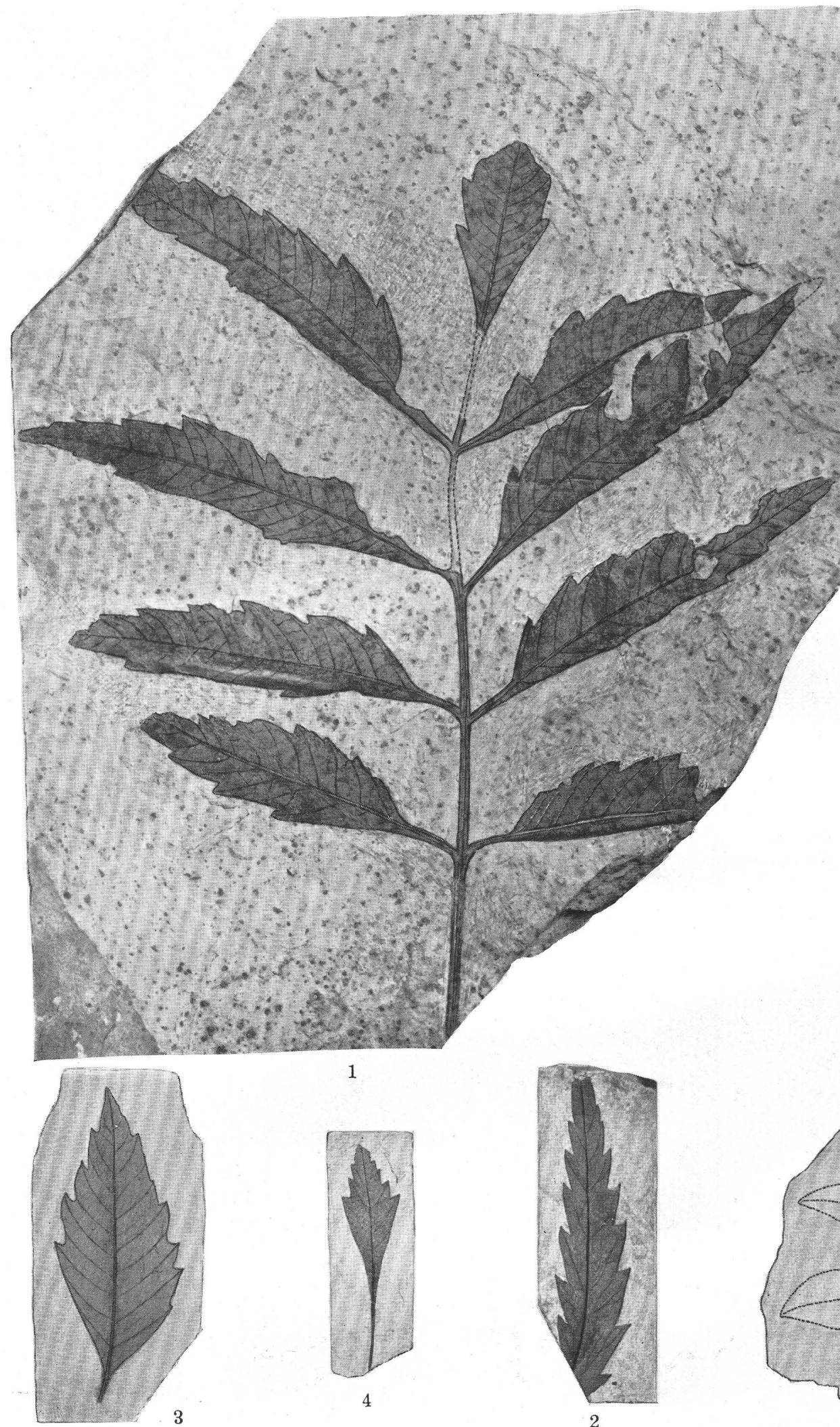


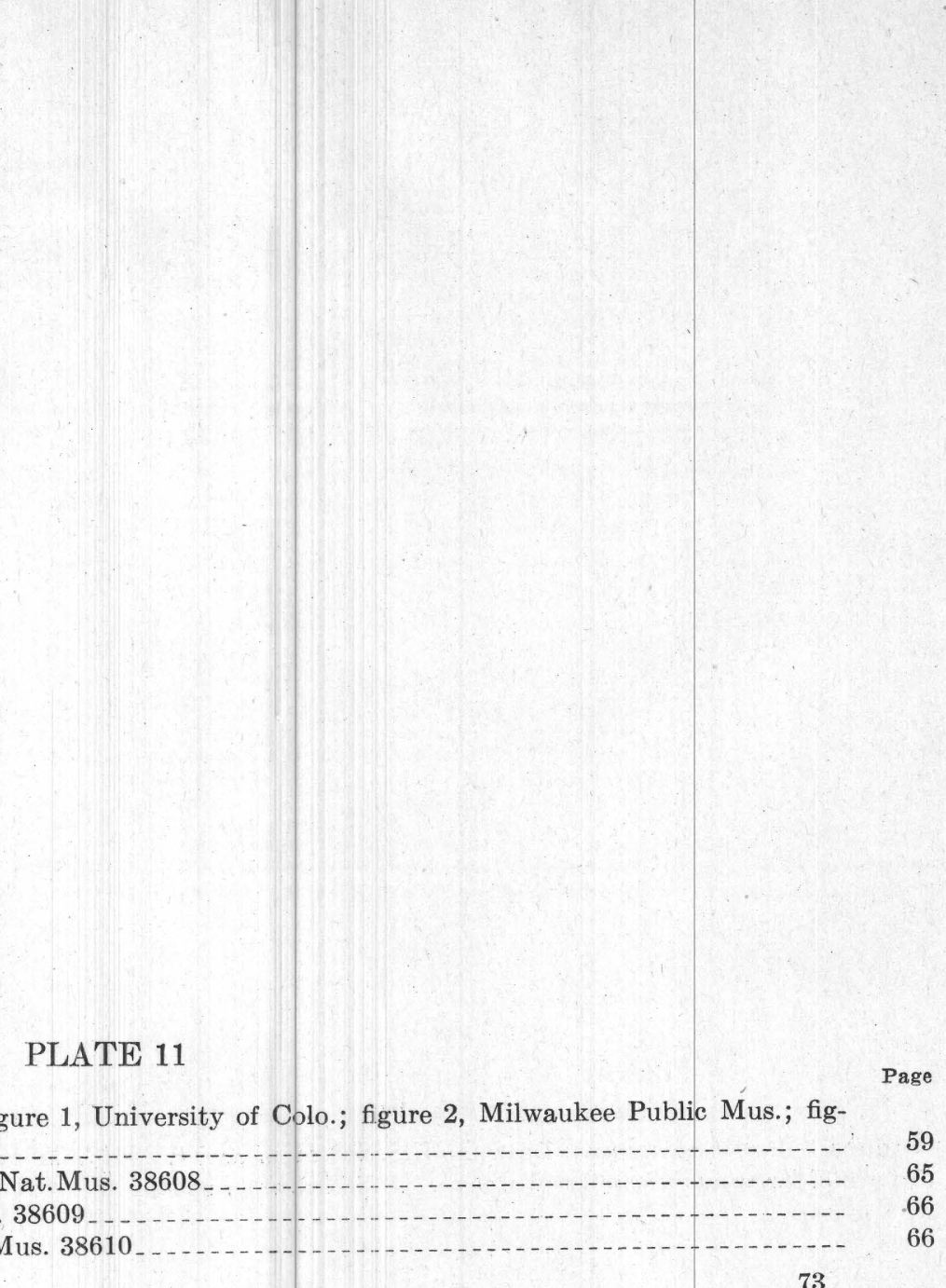

Figures 1-4. Rhus variabilis (Newberry) Knowlton. Figure 1, University of Colo.; figure 2, Milwaukee Public Mus.; figures 3, 4, U.S.Nat.Mus. 38606, 38607

59

Figure 5. Apocynophyllum roanense Brown, n.sp. U.S.Nat.Mus. 38608

Figure 6. Phyllites ouratea Brown, n.sp. U.S.Nat.Mus. 38609

Frgure 7. Phyllites glandiferus Brown, n.sp. U.S.Nat.Mus. 38610 
PLATE 12

Figures 1-4. eassia hesperia Brown. U.S.Nat.Mus. 38611, 38612, 38613, 38614

Figure 5. Fraxinus wieser Brown, n.sp. U.S.Nat.Mus. 38616 

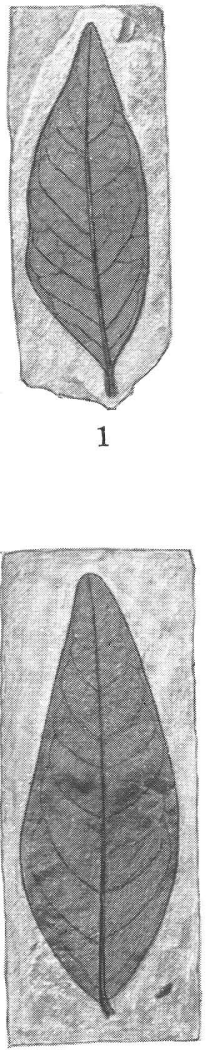

2

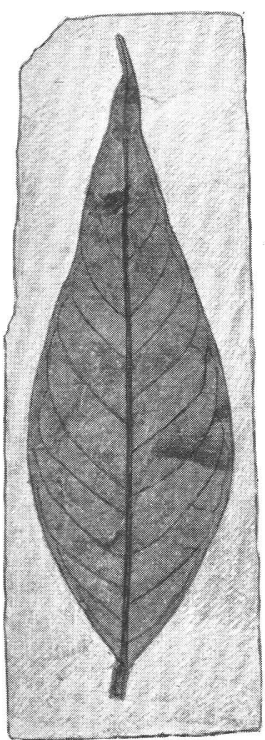

3

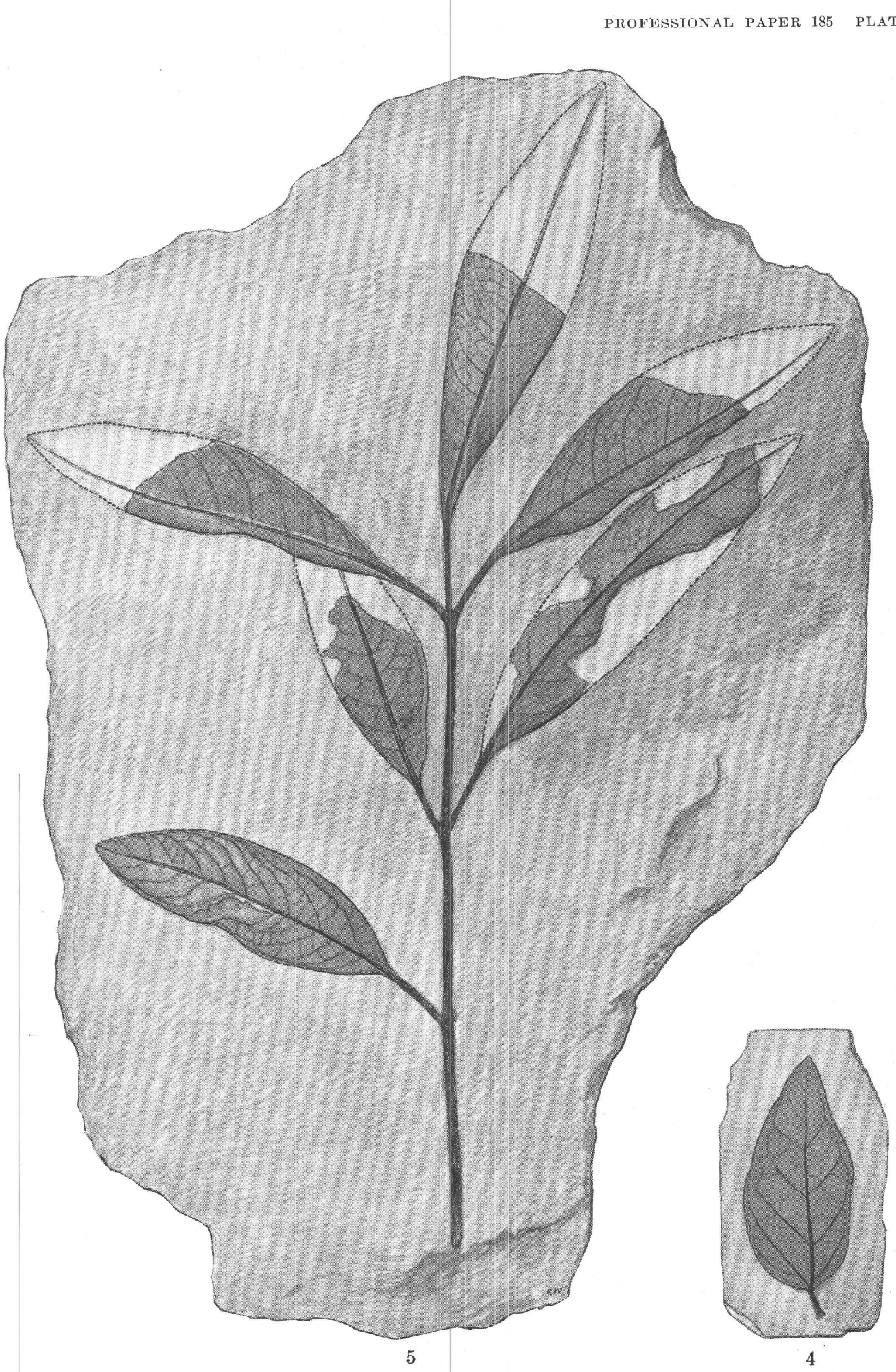

FOSSIL PLANTS FROM THE GREEN RIVER FORMATION. 


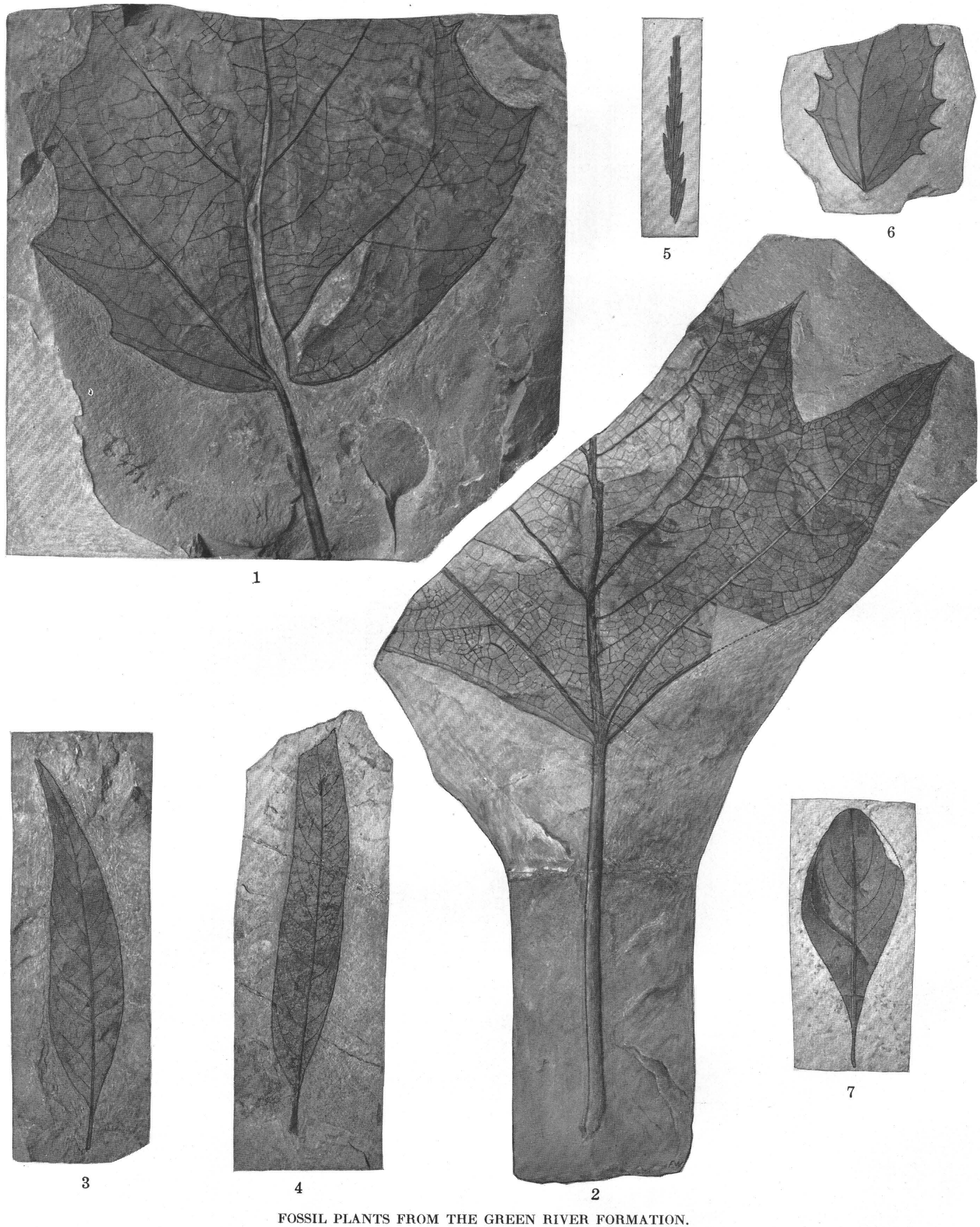




\section{PLATE 13}

FIGUR 1. Hibiscus roanensis Brown, n.sp. U.S.Nat.Mus. 38617

FIGURe 2. Cucurbita glandulosa Brown. U.S.Nat.Mus. 38618

Figures 3, 4. Sapindus dentoni Lesquereux. Agricultural and Mechanical College of Texas.

FIgURe 5. Phyllites furcivena Brown, n.sp. U.S.Nat.Mus. 38619

Figure 6. Odostemon eocenia Brown, n.sp. U.S.Nat.Mus. 38620

FIGURe 7. Phyllites ericoides Brown, n.sp. U.S.Nat.Mus. 38621 
PLATE 14

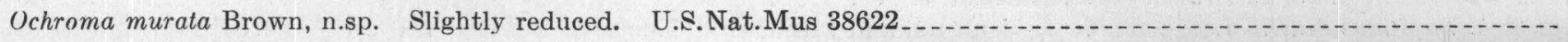




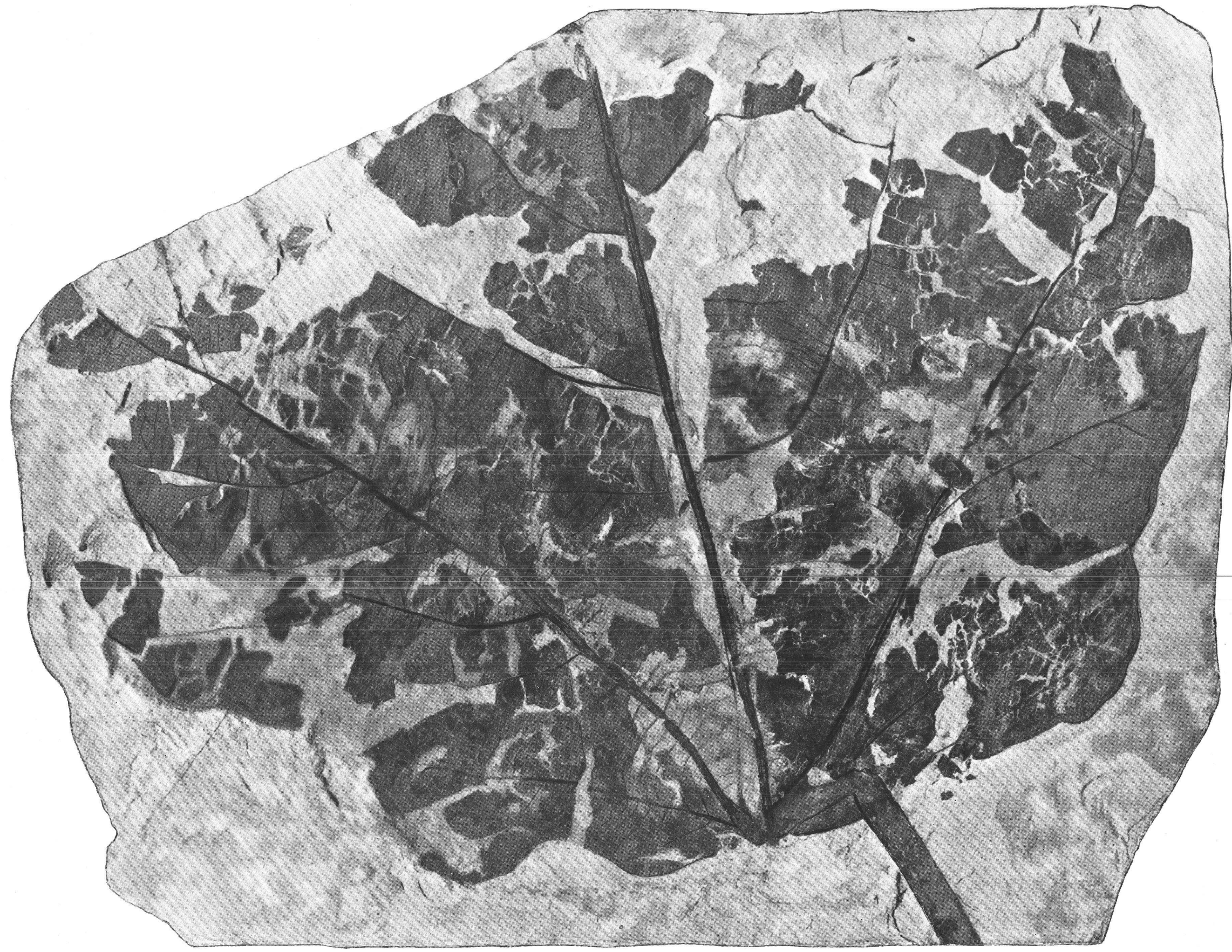

FOSSIL PLANT FROM THE GREEN RIVER FORMATION. 

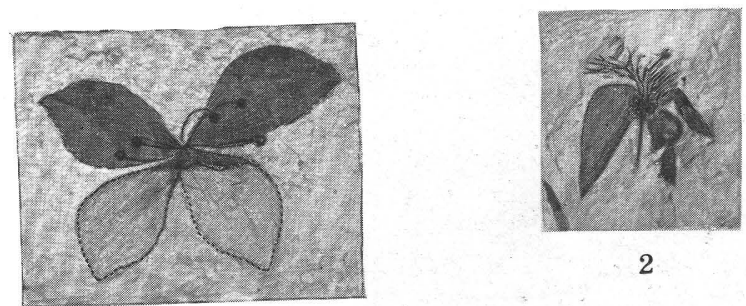

2

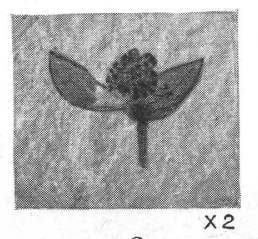

3

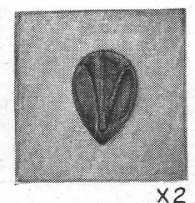

10

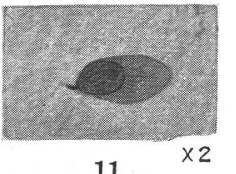

11

4
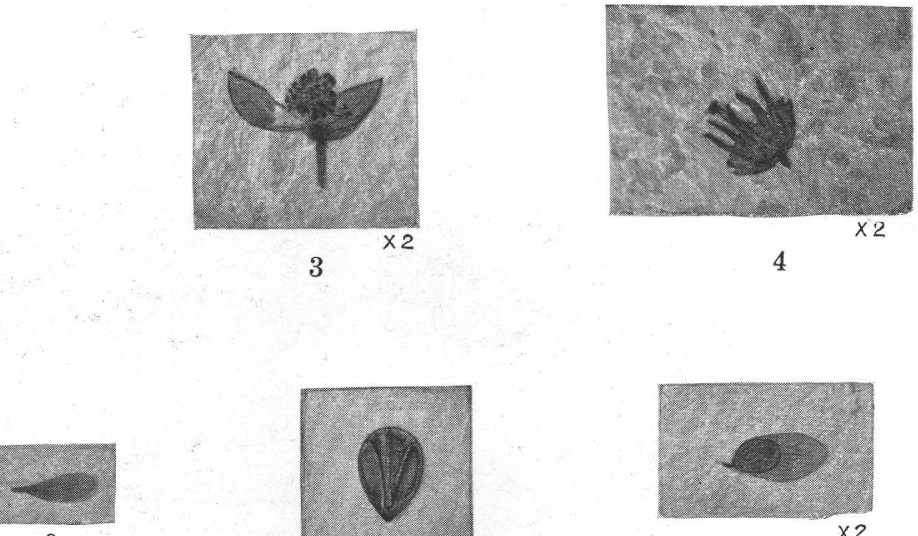

9

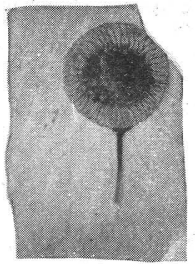

12

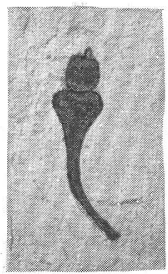

14

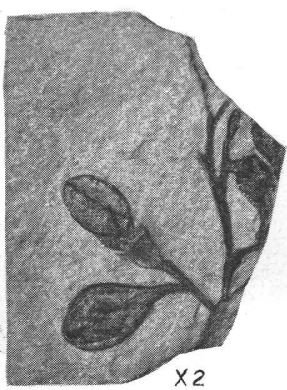

15

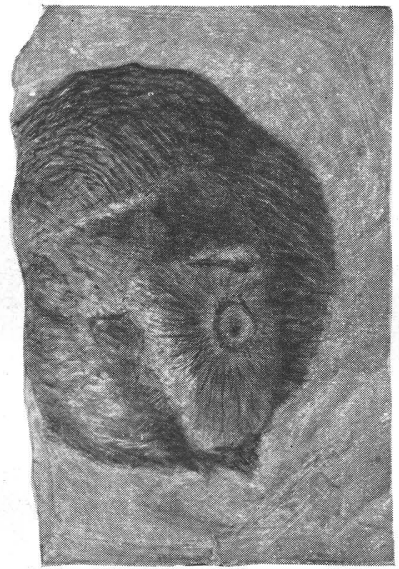

17

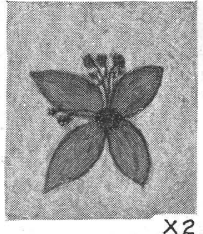

6
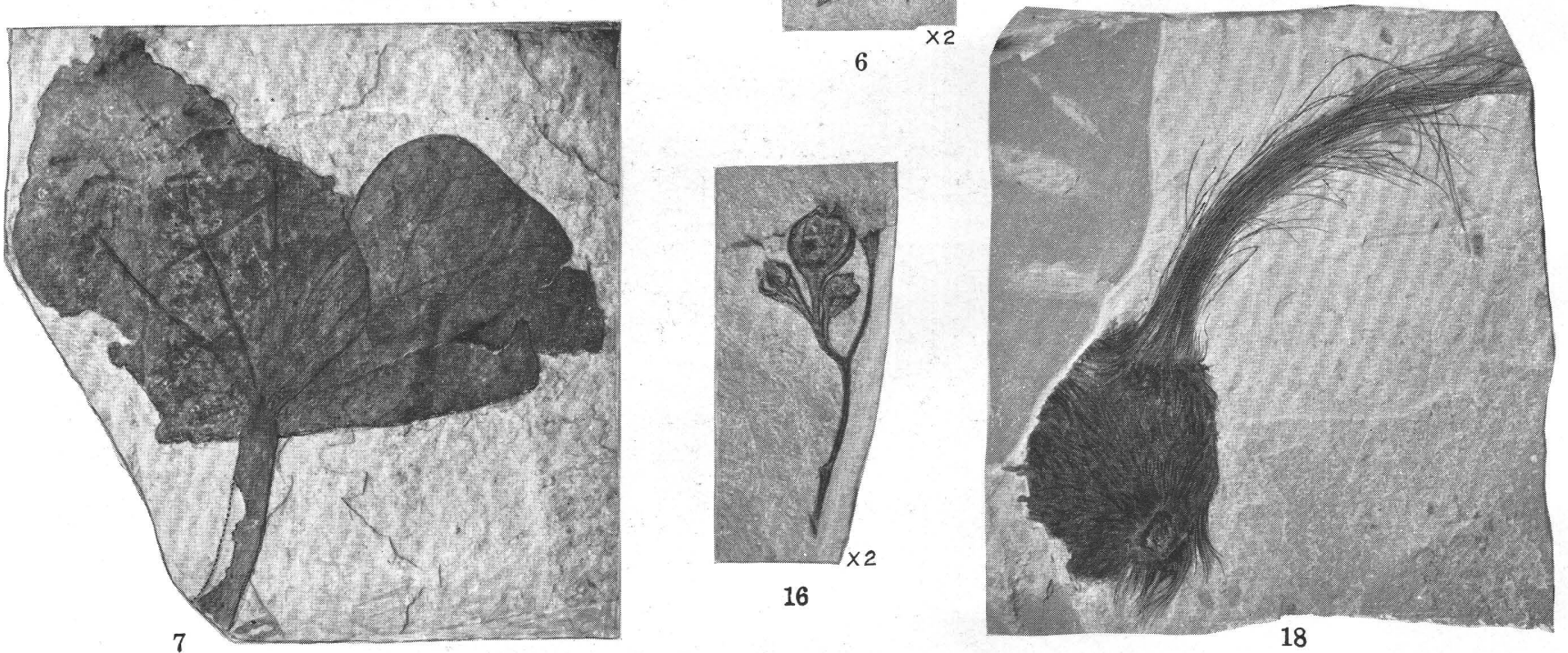

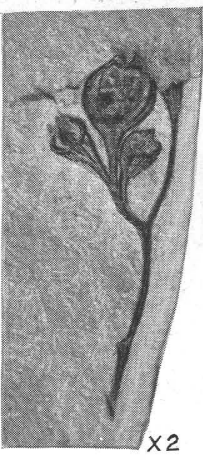

16

FOSSIL PLANTS FROM THE GREEN RIVER FORMATION. 
Figures 1-7. Antholithes, species of. U.S.Nat.Mus. 38623, 38624, 38625, 38626, 38627, 38628, 38628a

FIGURe 8. Carpolithus cassioides Brown, n.sp. U.S.Nat.Mus. 38629

Figure 9. Carpolithus insectoides Brown, n.sp. U.S.Nat.Mus. 38630

FIgURe 10. Carpolithus vitaceus Brown, n.sp. U.S.Nat.Mus. 38631

FIGURe 11. Carpolithus alabaccus Brown, n.sp. U.S.Nat.Mus. 38632

FIGURe 12. Carpolithus paliuroides Brown, n.sp. U.S.Nat.Mus. 38633

FIGURes 13-16. Carpolithus, species of. U.S.Nat.Mus. 38634, 38635, 38636, 38637

Figures 17, 18. Carpolithus filiferus Brown, n.sp. Figure 17, U.S.Nat.Mus. 38638; figure 18, Agricultural and Mechanical College of Texas

Figure 19. Anacardites schinus Brown, n.sp. U.S.Nat.Mus. 38639 
